\title{
Molecular distributions of dicarboxylic acids, ketocarboxylic acids and $\alpha$-dicarbonyls in biomass burning aerosols: implications for photochemical production and degradation in smoke layers
}

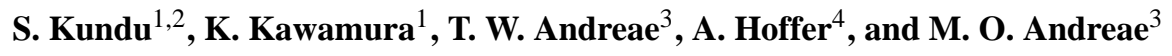 \\ ${ }^{1}$ Institute of Low Temperature Science, Hokkaido University, Sapporo, Japan \\ ${ }^{2}$ Graduate School of Environmental Science, Hokkaido University, Sapporo, Japan \\ ${ }^{3}$ Biogeochemistry Department, Max Planck Institute for Chemistry, Mainz, Germany \\ ${ }^{4}$ Department of Earth and Environmental Sciences, University of Pannonia, Veszprém, Hungary
}

Received: 15 July 2009 - Published in Atmos. Chem. Phys. Discuss.: 23 September 2009

Revised: 8 February 2010 - Accepted: 12 February 2010 - Published: 2 March 2010

\begin{abstract}
Aerosols in the size class $<2.5 \mu \mathrm{m}$ (6 daytime and 9 nighttime samples) were collected at a pasture site in Rondônia, Brazil, during the intensive biomass burning period of 16-26 September 2002 as part of the Large-Scale Biosphere-Atmosphere Experiment in Amazonia - Smoke, Aerosols, Clouds, Rainfall and Climate (LBA-SMOCC). Homologous series of dicarboxylic acids $\left(\mathrm{C}_{2}-\mathrm{C}_{11}\right)$ and related compounds (ketocarboxylic acids and $\alpha$-dicarbonyls) were identified using gas chromatography (GC) and GC/mass spectrometry (GC/MS). Among the species detected, oxalic acid was found to be the most abundant, followed by succinic, malonic and glyoxylic acids. Average concentrations of total dicarboxylic acids, ketocarboxylic acids and $\alpha$-dicarbonyls in the aerosol samples were 2180,167 and $56 \mathrm{ng} \mathrm{m}^{-3}$, respectively. These are $2-8,3-11$ and $2-16$ times higher, respectively, than those reported in urban aerosols, such as in 14 Chinese megacities. Higher ratios of dicarboxylic acids and related compounds to biomass burning tracers (levoglucosan and $\mathrm{K}^{+}$) were found in the daytime than in the nighttime, suggesting the importance of photochemical production. On the other hand, higher ratios of oxalic acid to other dicarboxylic acids and related compounds normalized to biomass burning tracers (levoglucosan and $\mathrm{K}^{+}$) in the daytime provide evidence for the possible degradation of dicarboxylic acids $\left(\geq C_{3}\right)$ in this smoke-polluted environment. Assuming that these and related compounds are photo-chemically oxidized to oxalic acid in the daytime, and given their linear relationship, they could account for, on av-
\end{abstract}

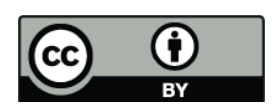

Correspondence to: K. Kawamura (kawamura@lowtem.hokudai.ac.jp) erage, $77 \%$ of the formation of oxalic acid. The remaining portion of oxalic acid may have been directly emitted from biomass burning as suggested by a good correlation with the biomass burning tracers $\left(\mathrm{K}^{+}, \mathrm{CO}\right.$ and $\left.\mathrm{EC}_{\mathrm{a}}\right)$ and organic carbon (OC). However, photochemical production from other precursors could not be excluded.

\section{Introduction}

The ubiquity of dicarboxylic acids and related compounds (ketocarboxylic acids and $\alpha$-dicarbonyls) is well recognized in atmospheric aerosols from urban (Kawamura and Kaplan, 1987; Kawamura and Ikushima, 1993; Limbeck and Puxbaum, 1999; Röhrl and Lammel, 2002; Wang et al., 2002; Fisseha et al., 2006; Ho et al., 2007), rural/suburban (Khwaja, 1995; Limbeck et al., 2001; Legrand et al., 2007), remote marine (Kawamura and Sakaguchi, 1999; Mochida et al., 2003a; Sempéré and Kawamura, 2003; Kawamura et al., 2004; Wang et al., 2006; Legrand et al., 2007), Arctic (Kawamura et al., 1996b; Kerminen et al., 1999; Narukawa et al., 2003) and Antarctic regions (Kawamura et al., 1996a). In contrast, there are relatively few reports on the molecular distributions and concentrations of dicarboxylic acids and ketocarboxylic acids in biomass burning aerosols (Allen and Miguel, 1995; Graham et al., 2002; Mayol-Bracero et al., 2002; Gao et al., 2003; Decesari et al., 2006; Falkovich et al., 2005), or biomass burning haze aerosols (Narukawa et al., 1999).

Although biomass burning is an important source of dicarboxylic acids and related compounds, none of the previous biomass burning aerosol studies has discussed the molecular

Published by Copernicus Publications on behalf of the European Geosciences Union. 
distributions of dicarboxylic acids and related compounds in the range of $C_{2}-C_{11}$ along with their formation and degradation pathways in biomass burning plumes. Molecular distributions of dicarboxylic acids and related compounds should provide information on the source and formation mechanisms of water-soluble organic aerosols in the biomass burning aerosols, which are poorly understood (Grosjean et al., 1989; Kawamura and Ikushima, 1993).

Dicarboxylic and ketocarboxylic acids account for 2-9\% of water-soluble organic carbon (WSOC) in biomass burning aerosols (Narukawa et al., 1999; Decesari et al., 2006; Falkovich et al., 2005). WSOC in biomass burning aerosols contributes to the CCN activity (Sherwood, 2002; Andreae et al., 2004; Mircea et al., 2005; Andreae and Rosenfeld, 2008; Asa-Awuku et al., 2008), which affects cloud microphysical properties and hence precipitation patterns and cloud albedo (Kaufman and Fraser, 1997; Ramanathan et al., 2001; Kaufman et al., 2002). Glutaric acid (a $\mathrm{C}_{5}$ dicarboxylic acid) has been found to increase the CCN activation ability of ammonium sulfate, a major inorganic species in atmospheric aerosols (Cruz and Pandis, 1997, 1998). Organics prevalent in biomass burning aerosols can also enhance their CCN ability via the depression of surface tension (Asa-Awuku et al., 2008).

Here we report on the molecular distribution and loadings of dicarboxylic acids and related compounds in the $\mathrm{C}_{2}-$ $\mathrm{C}_{11}$ range in biomass burning aerosol samples collected in Amazonia. The aerosol samples collected both in the dayand night-time allowed us to address their diurnal variations and hence chemical formation and degradation. The results are used to better understand their possible sources and formation processes in terms of primary versus secondary origin. We also discuss the day/night variations of dicarboxylic acids using biomass burning tracers $\left(\mathrm{K}^{+}, \mathrm{CO}, \mathrm{EC}_{\mathrm{a}}\right.$ and levoglucosan) and organic carbon (OC) previously measured in these samples (Hoffer et al., 2006; Fuzzi et al., 2007; Kundu et al., 2010).

\section{Experimental}

\subsection{Site description and aerosol sampling}

Aerosol sampling was carried out during an intensive biomass burning period (dry season), 16-26 September 2002, at the FNS (Fazenda Nossa Senhora Aparecida) site $\left(10^{\circ} 45^{\prime} 44^{\prime \prime} \mathrm{S}, 62^{\circ} 21^{\prime} 27^{\prime \prime} \mathrm{W}, 315 \mathrm{~m}\right.$ a.s.l.) located in the western province of Rondônia, Brazil (Andreae et al., 2002). Aerosol sampling procedures have been described in detail elsewhere (Hoffer et al., 2006). Briefly, fine aerosol particles $\left(\mathrm{PM}_{2.5}\right)$ were collected on pre-combusted $(\sim 10 \mathrm{~h}$ at $600^{\circ} \mathrm{C}$ ) Pallflex quartz fiber filters using a dichotomous virtual impactor (Solomon et al., 1983) mounted on a $10 \mathrm{~m}$ high tower. Daytime samples $(n=6)$ were collected from $\sim 07: 45$ to $\sim 17: 45 \mathrm{LT}$ (local time) and nighttime samples $(n=9)$ from $\sim$ 18:30 to $\sim 07: 00 \mathrm{LT}$. The aerosol filters were placed in prebaked glass jars and stored in a freezer at $-20^{\circ} \mathrm{C}$ at the Max Planck Institute for Chemistry in Mainz, Germany. Small fractions of the filter discs were transported to our laboratory in Sapporo, Japan, wrapped in pre-baked thick aluminum foil. Filter discs were transferred into pre-baked glass vials $\left(\sim 480^{\circ} \mathrm{C}\right.$, overnight) and stored at $-20^{\circ} \mathrm{C}$ until analysis.

\subsection{Analytical methods}

Filter samples were analyzed for water-soluble dicarboxylic acids, ketocarboxylic acids and $\alpha$-dicarbonyls (Kawamura and Ikushima, 1993; Kawamura, 1993). Briefly, aliquots of the filter samples were extracted with organic-free pure water $(2 \mathrm{ml} \times 3,18 \mathrm{M} \Omega)$ by ultrasonic agitation for the isolation of dicarboxylic acids and related compounds. The extracts were passed through a glass column (Pasteur pipette) packed with quartz wool in order to remove filter debris and insoluble particles and then concentrated to almost dryness using a rotary evaporator $\left(\sim 40^{\circ} \mathrm{C}\right)$. The concentrates were derivatized with $14 \%$ borontrifluoride in n-butanol at $100^{\circ} \mathrm{C}$ for one hour. The derived dibutyl esters and dibutoxy acetals were separated with $\mathrm{n}$-hexane $(\sim 5 \mathrm{ml})$ after adding pure water $(\sim 5 \mathrm{ml})$. The hexane layer was dried to ca. $50 \mu \mathrm{l}$ using a rotary evaporator, transferred to small vial ( $1.5 \mathrm{ml})$, dried to almost dryness by $\mathrm{N}_{2}$ blowdown, and dissolved in a known volume of $\mathrm{n}$ hexane (usually $50-100 \mu \mathrm{l}$ ). A $2 \mu \mathrm{l}$ aliquot of the sample was injected into a capillary GC instrument (Hewlett-Packard, HP6890) equipped with a split/splitless injector, fused silica capillary column (HP-5, $25 \mathrm{~m} \times 0.2 \mathrm{~mm}$ id. $\times 0.5 \mu \mathrm{m}$ film thickness) and FID detector. The oven temperature was held at $50^{\circ} \mathrm{C}$ for $2 \mathrm{~min}$, ramped at $30^{\circ} \mathrm{C} / \mathrm{min}$ to $120^{\circ} \mathrm{C}$, then at $6^{\circ} \mathrm{C} / \mathrm{min}$ to $310^{\circ} \mathrm{C}$ and held for $10 \mathrm{~min}$. Peak identification was carried out by comparison of the GC retention times with those of authentic standards (derivatives of $\mathrm{C}_{2}-\mathrm{C}_{11}$ dicarboxylic acids, glyoxylic acid, 4-oxobutanoic acid, pyruvic acid, glyoxal and methylglyoxal). Identification of esters and acetals was also confirmed by mass spectral analysis using a GC/MS instrument (Thermoquest, Trace MS) with similar GC column conditions. The quantification of the compounds was performed using the GC response factors of authentic standards. The GC peak areas were calculated with a Shimadzu C-R7A Plus integrator.

We spiked free dicarboxylic acids on pre-combusted quartz fiber filters in order to test the recovery. They were extracted and analyzed like the real samples. The recoveries ranged between $80-85 \%$ for oxalic acid and more than $90 \%$ for malonic, glutaric, succinic and adipic acids. Kawamura and Yasui (2005) reported that the recoveries were 88\%,72\% and $47 \%$ for glyoxylic acid, pyruvic acid and methylglyoxal, respectively, following the same analytical procedure in our laboratory. Repeated analyses of the filter sample showed that the analytical error of this method was less than $10 \%$ for major species reported in this study. A field blank showed small peaks of oxalic, succinic, adipic, and phthalic acids 
and methylglyoxal. However, their levels were very low $(0.1-2.6 \%)$ compared to those of the real samples. The reported concentrations for the samples are corrected for the field blanks, but not for recoveries.

\section{Results and discussions}

\subsection{Insignificant contribution from anthropogenic sources to biomass burning haze at the FNS site in Rondônia}

The LBA-SMOCC campaign at the FNS site in Rondônia was carried out from September to November 2002. Three periods were distinguished based on the concentrations of $\mathrm{PM}_{10}$, carbon monoxide (CO) and total carbon (TC) (Decesari et al., 2006; Fuzzi et al., 2007). The concentrations of $\mathrm{PM}_{10}$ measured by a Tapered Element Oscillating Microbalance (TEOM) and different types of cascade impactors during the dry period ( 7 September-7 October) were higher by a factor of 2.3-3.7 and 4.9-12.4, respectively, than those during the transition (8-30 October) and wet (30 October-14 November) periods. Furthermore, concentrations of $\mathrm{CO}$ and TC during the dry period were higher than those in other periods by a factor of 2.3-4.3, and 3.6-21.1, respectively. Falkovich et al. (2005) found that in this campaign the mean concentration of $\mathrm{C}_{2}-\mathrm{C}_{6}$ dicarboxylic acids in the dry period was 2.3 and 15.3 times higher than that in the transition and wet periods, respectively. Based on the high concentrations of pyrogenic aerosol components, the relatively low levels of fossil fuel components such as sulfate, the presence of a large number of fires, and the lack of substantial urban areas in the upwind region, Fuzzi et al. (2007) concluded that biomass smoke was the dominant aerosol component during the study period in Rondônia. This suggests that the contribution of dicarboxylic acids from other anthropogenic sources during the dry period is not important in our samples.

\subsection{Molecular distributions of dicarboxylic acids, keto- carboxylic acids and $\alpha$-dicarbonyls}

We measured dicarboxylic acids and related compounds in the range of $\mathrm{C}_{2}-\mathrm{C}_{11}$ in the aerosol particles collected during the intensive biomass burning period from the FNS site in Rondônia. Figure 1 shows the molecular distributions of dicarboxylic acids and related compounds in the day and night samples.

Among the smaller-MW (molecular weight) saturated ndicarboxylic acids $\left(\mathrm{C}_{2}-\mathrm{C}_{4}\right)$, oxalic $\left(\mathrm{C}_{2}\right)$ acid was the most abundant species followed by succinic $\left(\mathrm{C}_{4}\right)$ and malonic $\left(\mathrm{C}_{3}\right)$ acids in all samples. The predominance of oxalic $\left(\mathrm{C}_{2}\right)$ acid has been reported for biomass burning aerosols (Narukawa et al., 1999; Graham et al., 2002; Mayol-Bracero et al., 2002; Gao et al., 2003; Decesari et al., 2006; Falkovich et al., 2005), atmospheric aerosols and rain samples from urban areas (Kawamura and Ikushima, 1993; Kawamura et al., 2001;
Wang et al., 2002) and remote marine regions (Sempéré and Kawamura, 1996; Kawamura and Sakaguchi, 1999; Mochida et al., 2003b) as well as for Arctic aerosols (Kawamura et al., 1996a), with the exception that a few Antarctic aerosol samples showed a higher abundance for succinic $\left(\mathrm{C}_{4}\right)$ acid (Kawamura et al., 1996b). The three species accounted for, on average, $63 \%, 12 \%$ and $9 \%$ of the total dicarboxylic acids in the daytime samples, and for $62 \%, 14 \%$ and $8 \%$ in the nighttime samples, respectively. Among the larger-MW (molecular weight, $\mathrm{C}_{5}-\mathrm{C}_{11}$ ) saturated n-dicarboxylic acids, adipic $\left(\mathrm{C}_{6}\right)$ acid is the most abundant in the daytime while glutaric $\left(\mathrm{C}_{5}\right)$ acid is the most abundant in the nighttime followed by azelaic $\left(\mathrm{C}_{9}\right)$ acid. These larger-MW dicarboxylic acids, on average, contributed $\sim 7 \%$ of total dicarboxylic acids in both day and night samples.

Among branched, unsaturated aliphatic, unsaturated aromatic and multifunctional dicarboxylic acid groups, major species are methylsuccinic $\left(\mathrm{iC}_{5}\right)$, maleic $(\mathrm{M})$, phthalic $(\mathrm{Ph})$ and malic $\left(\mathrm{hC}_{4}\right)$ acids, respectively, in all day and night samples. The mean concentration of terephthalic $(\mathrm{tPh})$ acid in both day and night samples is $\sim 36-43 \%$ higher than that of isophthalic (iPh) acid. Glyoxylic $\left(\omega \mathrm{C}_{2}\right)$ acid, a $\omega$ oxocarboxylic acid, is the fourth abundant among all the dicarboxylic acids and related compounds determined. It accounted for $77 \%$ of total ketocarboxylic acids in day samples versus $80 \%$ in night samples. Its contribution to total dicarboxylic acids plus related compounds was found to be $6 \%$ in day samples and 5\% in night samples.

A predominance of oxalic $\left(\mathrm{C}_{2}\right)$ acid followed by succinic $\left(\mathrm{C}_{4}\right)$, malonic $\left(\mathrm{C}_{3}\right)$ and glyoxylic $(\omega \mathrm{C} 2)$ acids was observed throughout the campaign in all day and night samples. The next most abundant species are glutaric $\left(\mathrm{C}_{5}\right)$ and phthalic $(\mathrm{Ph})$ acids, whose mean concentrations are almost equal in the day samples, whereas glutaric $\left(\mathrm{C}_{5}\right)$ acid is much more abundant than phthalic $(\mathrm{Ph})$ acid in the night samples. This type of molecular distribution is different from that found for 14 Chinese megacities, where for example, phthalic acid is the second most abundant dicarboxylic acid in 11 cities in summertime and in 7 cities in wintertime (Ho et al., 2007). Oxalic $\left(\mathrm{C}_{2}\right)$ acid was found to be the dominant species, followed by malonic $\left(\mathrm{C}_{3}\right)$ and succinic $\left(\mathrm{C}_{4}\right)$ acids, in aerosols of urban Tokyo and Vienna, while the next abundant were glyoxylic $\left(\omega \mathrm{C}_{2}\right)$, phthalic $(\mathrm{Ph})$ and glutaric $\left(\mathrm{C}_{5}\right)$ acids in the case of Tokyo aerosols, and glutaric $\left(\mathrm{C}_{5}\right)$, glyoxylic $\left(\omega \mathrm{C}_{2}\right)$ and phthalic $(\mathrm{Ph})$ acids in the case of Vienna aerosols (Limbeck and Puxbaum, 1999; Sempéré et al., 1994). Kawamura and Kaplan (1987) have reported the predominance of oxalic $\left(\mathrm{C}_{2}\right)$ acid followed by succinic, phthalic $(\mathrm{Ph})$, malonic $\left(\mathrm{C}_{3}\right)$ and glutaric $\left(\mathrm{C}_{5}\right)$ acids in aerosols of downtown Los Angeles. They have also reported higher abundance of oxalic $\left(\mathrm{C}_{2}\right)$ acid followed by succinic $\left(\mathrm{C}_{4}\right)$, malonic $\left(\mathrm{C}_{3}\right)$, phthalic $(\mathrm{Ph})$ and glutaric $\left(\mathrm{C}_{5}\right)$ acids in aerosols of west Los Angeles. 
(a) Daytime samples



Fig. 1. Averaged molecular distributions of dicarboxylic acids, ketocarboxylic acids and $\alpha$-dicarbonyls in (a) daytime and (b) nighttime samples collected during the intensive biomass burning period from the FNS site in Rondônia, Brazil. See Table 1 for abbreviations. The error bars represent one standard deviation.

Table 1 presents the concentration ranges and average concentrations of dicarboxylic acids and related compounds determined in day and night samples, as well as their chemical formulas. Although the boundary layer height (average $1690 \pm 250 \mathrm{~m}$ ) in the daytime is $\sim 7.5$ times higher than in the nighttime (200-250 m) (Rissler et al., 2006), higher concentrations of all dicarboxylic acids and related compounds except terephthalic and ketomalonic acids were observed in a day sample (see upper limit of the range in Table 1). Probably, this is due to the comparatively thick smoke conditions in daytime. It is of interest that although average concentrations of most dicarboxylic acids and related compounds were higher by $11-20 \%$ in nighttime than in daytime, pimelic $\left(\mathrm{C}_{7}\right)$, azelaic $\left(\mathrm{C}_{9}\right)$, sebacic $\left(\mathrm{C}_{10}\right)$, phthalic $(\mathrm{Ph})$, hydrox- ysuccinic $\left(\mathrm{hC}_{4}\right), 3$-oxopropanoic $\left(\omega \mathrm{C}_{3}\right)$ and glyoxal (Gly) showed almost equal or higher concentrations in the daytime (Table 1).

Succinic $\left(\mathrm{C}_{4}\right)$ acid has been suggested to be a precursor of malonic $\left(C_{3}\right)$ acid (Kawamura et al., 1996b). The mean ratio of $\mathrm{C}_{3} / \mathrm{C}_{4}$ in this study is 0.81 in daytime versus 0.59 in nighttime, which is higher than that for vehicular aerosols (average 0.35, Kawamura and Kaplan, 1987), but similar to that of urban aerosols (0.86 in summer versus 0.61 in winter, Ho et al., 2007). Maleic (M) acid can convert into fumaric $(\mathrm{F})$ acid during photochemical isomerization reactions (Kawamura and Ikushima, 1993). M/F ratios in all day and night samples ranged between 0.3-5.6 (average 2.8). This is in contrast to the urban aerosols $(0.8-3.9$, average 
Table 1. Concentrations of dicarboxylic acids, ketocarboxylic acids and $\alpha$-dicarbonyls detected in biomass burning aerosols collected during the LBA-SMOCC campaign at the FNS site in Rondônia, Brazil.

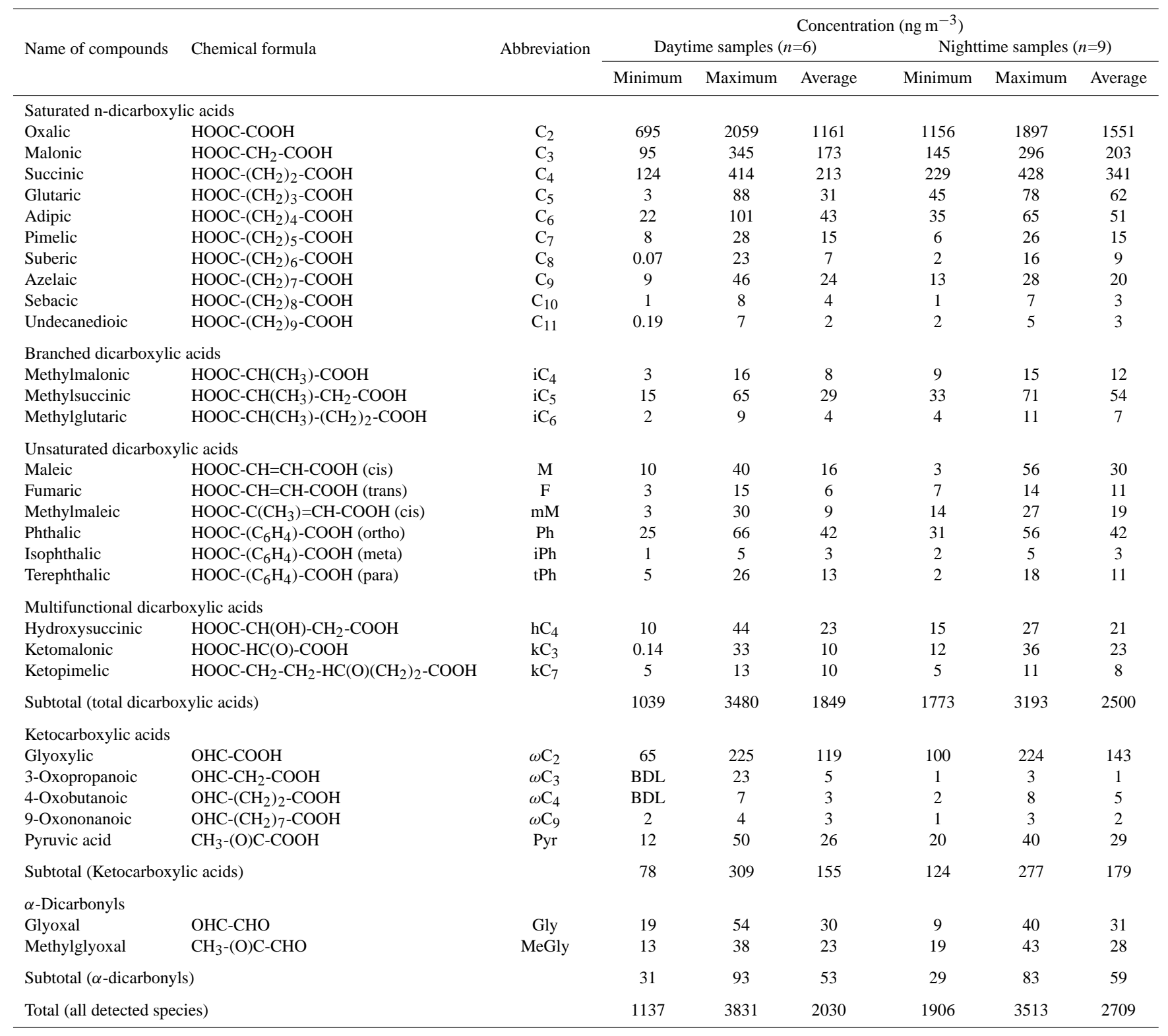

1.5) (Kawamura and Ikushima, 1993) and marine aerosols (0.06-1.3, average 0.26) (Kawamura and Sakaguchi, 1999). This study may suggest that the isomerization of maleic (M) acid to fumaric $(\mathrm{F})$ acid is suppressed under hazy conditions caused by biomass burning, in which sunlight is limited.

Adipic $\left(\mathrm{C}_{6}\right)$ and phthalic $(\mathrm{Ph})$ acids are produced by the oxidation of anthropogenic cyclohexene and aromatic hydrocarbons, whereas azelaic $\left(\mathrm{C}_{9}\right)$ acid is from biogenic unsaturated fatty acids containing a double bond at C-9 position (Kawamura and Gagosian, 1987; Kawamura and Ikushima,
1993). Consequently, $\mathrm{C}_{6} / \mathrm{C}_{9}$ and $\mathrm{Ph} / \mathrm{C}_{9}$ ratios can be used as markers to evaluate the source strength of anthropogenic versus biogenic precursors to dicarboxylic acids. The mean value of the $\mathrm{C}_{6} / \mathrm{C}_{9}$ ratio (2.2 for day and night samples) in our study is about 2-3 times higher than that for urban Chinese and Tokyo aerosols (Kawamura and Yasui, 2005; Ho et al., 2007), suggesting that adipic $\left(\mathrm{C}_{6}\right)$ acid is also derived from biomass burning. This finding is in contrast to the study of Narukawa et al. (1999), in which an increase of all dicarboxylic acids in the range of $\mathrm{C}_{2}-\mathrm{C}_{12}$ except adipic $\left(\mathrm{C}_{6}\right)$ acid 




Fig. 2. Diurnal variations in the carbon-based concentration ratios of (a) smaller-molecular weight $\left(\mathrm{C}_{2}, \mathrm{C}_{3}\right.$ and $\left.\mathrm{C}_{4}\right)$, (b) largermolecular weight $\left(\mathrm{C}_{5}, \mathrm{C}_{6}, \mathrm{C}_{7}\right.$ and $\left.\mathrm{C}_{9}\right)$, (c) branched $\left(\mathrm{iC}_{4}, \mathrm{iC}_{5}\right.$ and $\left.\mathrm{iC}_{6}\right)$, (d) aliphatic unsaturated $(\mathrm{M}, \mathrm{F}$ and $\mathrm{mM})$, (e) aromatic unsaturated $(\mathrm{Ph}, \mathrm{iPh}$ and $\mathrm{tPh})$ and (f) multifunctional $\left(\mathrm{hC}_{4}, \mathrm{kC}_{3}\right.$ and $\left.\mathrm{kC}_{7}\right)$ dicarboxylic acids, $(\mathbf{g}-\mathbf{h})$ ketocarboxylic acids $\left(\omega \mathrm{C}_{2}, \omega \mathrm{C}_{9}\right.$ and $\left.\mathrm{Pyr}\right)$ and (i) $\alpha$-dicarbonyls (MeGly and Gly) to levoglucosan in biomass burning aerosols. See Table 1 for abbreviations.

during fire-induced haze events in southeast Asia was observed. The mean value of the $\mathrm{Ph} / \mathrm{C}_{9}$ ratio in our study is 2-4 times lower than that of aerosols collected from Chinese megacities (Ho et al., 2007) and urban Los Angeles (Kawamura and Kaplan, 1987). This further supports that the

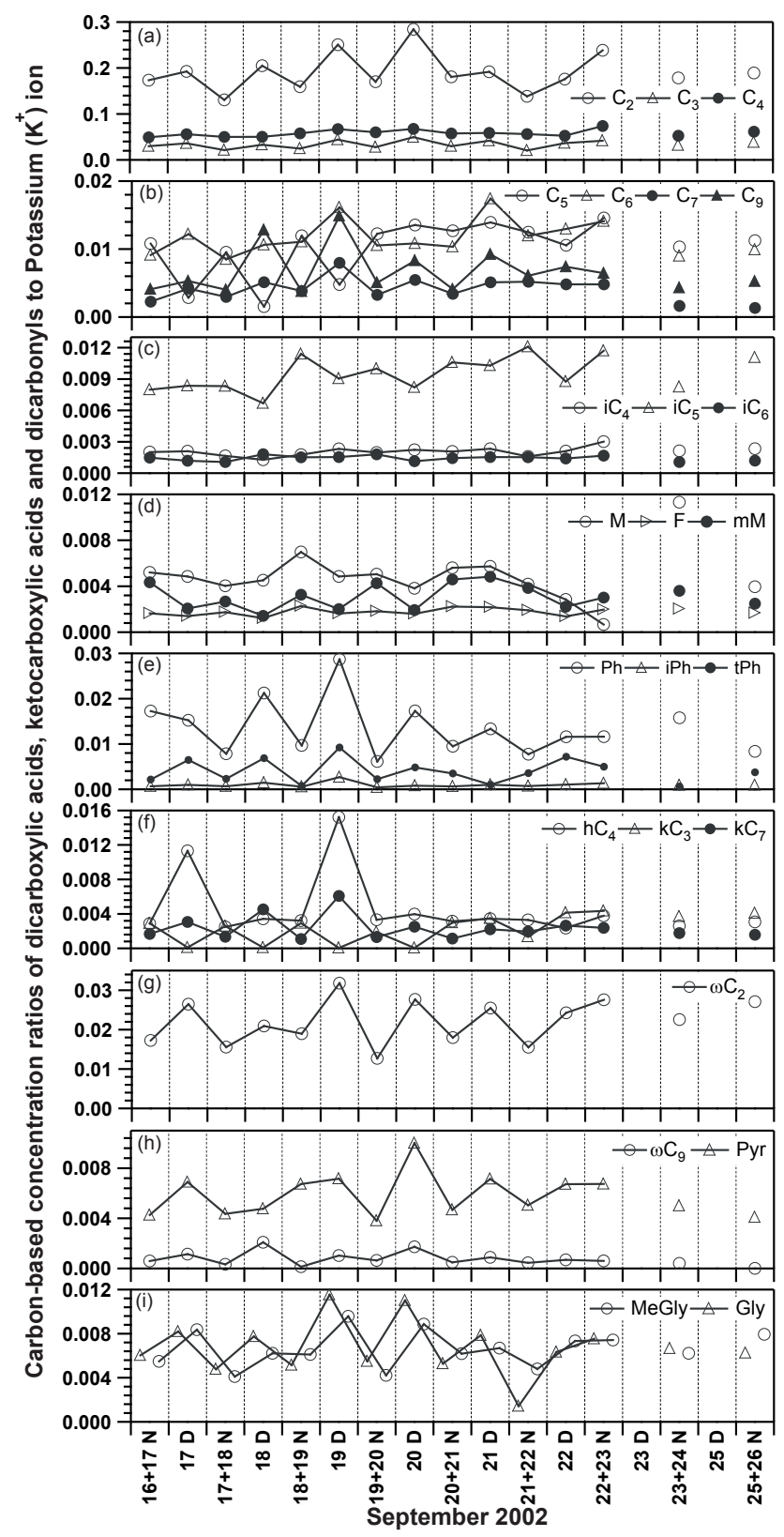

Fig. 3. Diurnal variations in the carbon-based concentration ratios of (a) smaller-molecular weight $\left(\mathrm{C}_{2}, \mathrm{C}_{3}\right.$ and $\left.\mathrm{C}_{4}\right)$, (b) largermolecular weight $\left(\mathrm{C}_{5}, \mathrm{C}_{6}, \mathrm{C}_{7}\right.$ and $\left.\mathrm{C}_{9}\right)$, (c) branched $\left(\mathrm{iC}_{4}, \mathrm{iC}_{5}\right.$ and $\mathrm{iC}_{6}$ ), (d) aliphatic unsaturated (M, F and $\left.\mathrm{mM}\right)$, (e) aromatic unsaturated $(\mathrm{Ph}, \mathrm{iPh}$ and $\mathrm{tPh})$ and (f) multifunctional $\left(\mathrm{hC}_{4}, \mathrm{kC}_{3}\right.$ and $\left.\mathrm{kC}_{7}\right)$ dicarboxylic acids, $(\mathbf{g}-\mathbf{h})$ ketocarboxylic acids $\left(\omega \mathrm{C}_{2}, \omega \mathrm{C}_{9}\right.$ and $\left.\mathrm{Pyr}\right)$ and (i) $\alpha$-dicarbonyls (MeGly and Gly) to potassium ion in biomass burning aerosols. See Table 1 for abbreviations.

contribution of phthalic ( $\mathrm{Ph})$ acid from other anthropogenic sources is less than from biomass burning. 


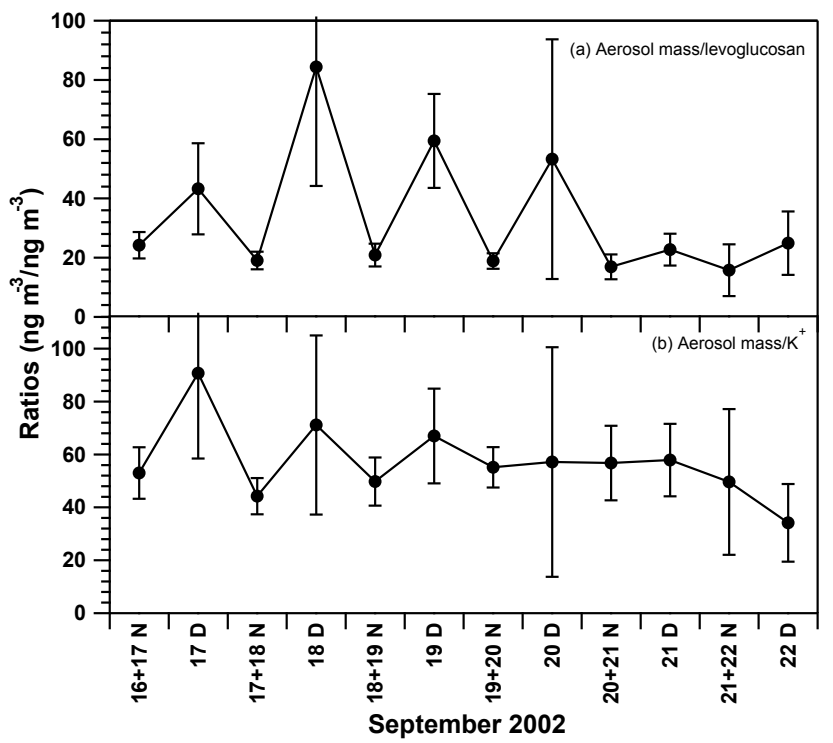

Fig. 4. Diurnal variations in the ratios of (a) aerosol mass to levoglucosan and (b) aerosol mass to $\mathrm{K}^{+} . \mathrm{PM}_{2.5}$ concentrations were determined every $30 \mathrm{~min}$ using a Tapered Element Oscillating Microbalance (TEOM) during the period 16-22 September 2002.

\subsection{High loadings of dicarboxylic acids and related compounds}

The average concentrations of total dicarboxylic acids, ketocarboxylic acids and $\alpha$-dicarbonyls along with their concentration ranges are shown in Table 1. Kundu et al. (2010) already reported for the same set of samples that they accounted for nearly $2.4 \%$ and $1.6 \%$ of OC in day- and nighttime samples, respectively. Ho et al. (2007) reported dicarboxylic acids and related compounds in atmospheric aerosols collected from 14 Chinese megacities during summer and winter (Table 2). The mean concentrations of total dicarboxylic acids $\left(2180 \mathrm{ng} \mathrm{m}^{-3}\right)$, total ketocarboxylic acids $\left(167 \mathrm{ng} \mathrm{m}^{-3}\right)$ and total dicarbonyls $\left(56 \mathrm{ng} \mathrm{m}^{-3}\right)$ for all day and night samples in our study were found to be higher by 1.6-7.6, 2.6-10.7 and 2.1-16.3 times, respectively, than those of 14 Chinese megacities. Table 2 compares concentration data of $\mathrm{C}_{2}-\mathrm{C}_{5}$ dicarboxylic acids with those reported in atmospheric aerosols collected from urban, semiurban/rural areas and remote marine islands located in different parts of the world as well as oceans and polar regions. The mean concentration of total $\mathrm{C}_{2}-\mathrm{C}_{5}$ dicarboxylic acids in our study is about 2-10 times higher than those from East Asian, European and North American megacities. Similarly, our mean concentration is about an order of magnitude higher than those of semiurban/rural aerosols and remote marine aerosols, and one to two orders of magnitude higher than those of the aerosols collected from remote oceans and polar regions. These comparisons clearly suggest that biomass burning is an important source of dicarboxylic acids in the atmosphere.

\subsection{Diurnal variations of the concentrations of dicar- boxylic acids and related compounds}

We have observed that the concentrations of dicarboxylic acids and related compounds normalized by the biomass burning tracers (levoglucosan and $\mathrm{K}^{+}$) are higher in the daytime than in the nighttime (Figs. 2 and 3). For example, the normalized concentrations of oxalic $\left(\mathrm{C}_{2}\right)$, malonic $\left(\mathrm{C}_{3}\right)$ and succinic $\left(\mathrm{C}_{4}\right)$ acids increased in daytime compared to nighttime by a factor of 1.2 to 4.6. Similar daytime enhancements in the normalized concentrations were found for most other acid and aldehyde species (Figs. 2 and 3). On the other hand, the normalized concentrations of glutaric $\left(\mathrm{C}_{5}\right)$ acid were 0.3 to 0.8 times lower in daytime than in nighttime for the first three pairs of successive day and night samples, but were 1.4 to 3.2 times higher in the remaining daytime samples. Some plausible mechanisms to explain these observations are suggested below.

Diurnal variations of aerosol mass to levoglucosan and to $\mathrm{K}^{+}$ratios with the maximum values at day (Fig. 4) are due to the predominance of biomass burning. Higher biomass burning in the daytime can emit large quantities of non-methane hydrocarbons (NMHC), among which unsaturated hydrocarbons are especially abundant (Andreae and Merlet, 2001; Koppmann et al., 2005). Unsaturated NMHC (e.g., ethene, ethyne, propene, butene, isoprene, cycloalkenes, pinene, etc.) can either be oxidized to dicarboxylic acids and related compounds and subsequently partitioned into the gas and aerosol phase (Gao et al., 2001), or be oxidized to aldehydes and ketones, which dissolve into aerosols and are then oxidized to organic acids in aqueous-phase reactions in the daytime (Gao et al., 2001). Alternatively, Gao et al. (2003) suggested that large organic molecules emitted from biomass burning might be degraded in the daytime to smaller molecules due to heterogeneous oxidation reactions. They invoked this logic based on the enrichment of oxalate, glutarate and succinate with respect to $\mathrm{K}^{+}$by an order of magnitude, when fresh biomass burning plumes from savanna fires age for about $40 \mathrm{~min}$. In the other words, lower ratios of dicarboxylic acids to biomass burning tracers at night (Figs. 2 and 3) are associated with less prevalence of biomass burning as suggested by Fig. 4 and the cessation of photochemical oxidation of NMHC and particulate organic matter due to the absence of sunlight.

Limbeck et al. (2001) reported the semivolatile behavior of $\mathrm{C}_{2}-\mathrm{C}_{9}$ dicarboxylic acids, glyoxylic and phthalic acids on aerosols collected using a low volume sampler equipped with a front/back-up filter tandem system of quartz fiber filters. They found that species detected on the back filter accounted for 13.3 to $38.5 \%$ of observed concentrations on the front filter, except for malonic acid. Therefore, it is likely that more dicarboxylic acids and related compounds will be partitioned to the aerosol phase in nighttime when the ambient temperature decreases. However, this condensation process cannot be more significant than the possible photoproduction, as 
Table 2. Comparison between the results of this study and other study results for the average concentrations of $\mathrm{C}_{2}-\mathrm{C}_{5}\left(\mathrm{ng} \mathrm{m}^{-3}\right)$ dicarboxylic acids in atmospheric aerosols.

\begin{tabular}{|c|c|c|c|c|c|c|}
\hline Name of site & Oxalic & Malonic & Succinic & Glutaric & Total & References \\
\hline \multicolumn{7}{|l|}{ Urban } \\
\hline Hong Kong, China & 618 & 92 & 68 & 16 & 794 & Ho et al. (2007) \\
\hline Guangzhou, China & 948 & 66 & 81 & 23 & 1118 & Ho et al. (2007) \\
\hline Xiamen, China & 648 & 47 & 61 & 17 & 773 & Ho et al. (2007) \\
\hline Chongqing, China & 639 & 41 & 109 & 29 & 818 & Ho et al. (2007) \\
\hline Hangzhou, China & 723 & 52 & 79 & 26 & 880 & Ho et al. (2007) \\
\hline Wuhan, China & 628 & 49 & 80 & 21 & 778 & Ho et al. (2007) \\
\hline Shanghai, China & 537 & 63 & 87 & 28 & 715 & Ho et al. (2007) \\
\hline Xi' an, China & 802 & 61 & 148 & 62 & 1073 & Ho et al. (2007) \\
\hline Qingdao, China & 283 & 18 & 43 & 13 & 357 & Ho et al. (2007) \\
\hline Yulin, China & 267 & 39 & 43 & 14 & 363 & Ho et al. (2007) \\
\hline Jinchang, China & 155 & 13 & 20 & 9 & 197 & Ho et al. (2007) \\
\hline Tianjin, China & 400 & 42 & 78 & 34 & 554 & Ho et al. (2007) \\
\hline Beijing, China & 553 & 47 & 77 & 35 & 712 & Ho et al. (2007) \\
\hline Changchun, China & 345 & 40 & 82 & 29 & 496 & Ho et al. (2007) \\
\hline Nanjing, China & 660 & 89 & 113 & 48 & 910 & Wang et al. (2002) \\
\hline Tokyo, Japan & 270 & 55 & 37 & 11 & 373 & Kawamura and Ikushima (1993) \\
\hline Zurich, Switzerland & 122 & 21 & 9 & 4 & 156 & Fisseha et al. (2006) \\
\hline Viena, Austria & 340 & 244 & 117 & 26 & 727 & Limbeck and Puxbaum (1999) \\
\hline Leipzip, Germany & 229 & 66 & 35 & & 330 & Röhrl and Lammel (2002) \\
\hline Los Angeles, USA & 513 & 80 & 172 & 59 & 824 & Kawamura and Kaplan (1987) \\
\hline \multicolumn{7}{|l|}{ Semiurban/rural } \\
\hline Puy de Dôme, France & 137 & 29 & 12 & 9 & 187 & Legrand et al. (2007) \\
\hline K-puszta, Hungary & 282 & 29 & 29 & 20 & 360 & Legrand et al. (2007) \\
\hline New York, USA & 231 & 119 & 84 & & 434 & Khwaja (1995) \\
\hline Nylsvley Nature Reserve (S. Africa) & 79 & 52 & 13 & 1.9 & 146 & Limbeck et al. (2001) \\
\hline \multicolumn{7}{|l|}{ Remote marine Islands } \\
\hline Gosan, South Korea & 473 & 67 & 52 & 11 & 603 & Kawamura et al. (2004) \\
\hline Chichi-jima Island, Japan & 91 & 13 & 8 & 1.6 & 114 & Mochida et al. (2003a) \\
\hline Azores, Portugal & 54 & 6 & 2 & 1.3 & 63 & Legrand et al. (2007) \\
\hline \multicolumn{7}{|l|}{ Coastal site/Open Ocean } \\
\hline Aveiro, Portugal & 265 & 25 & 20 & 13 & 323 & Legrand et al. (2007) \\
\hline Southern Ocean $\left(>50^{\circ} \mathrm{S}, 130-150^{\circ} \mathrm{E}\right)$ & 2.4 & 0.8 & 0.4 & 0.1 & 4 & Wang et al. (2006) \\
\hline Western Pacific $\left(35^{\circ} \mathrm{N}-50^{\circ} \mathrm{S}\right)$ & 38 & 12 & 5 & 1.2 & 56 & Wang et al. (2006) \\
\hline Western Pacific $\left(5^{\circ} \mathrm{N}-40^{\circ} \mathrm{S}\right)$ & 2.8 & 1 & 0.8 & 0.3 & 5 & Sempéré and Kawamura (2003) \\
\hline Tropical to Western North Pacific & 40 & 11 & 2.8 & 0.6 & 54 & Kawamura and Sakaguchi (1999) \\
\hline \multicolumn{7}{|l|}{ Polar regions } \\
\hline Alert, Canada & 9.5 & 2.9 & 4.1 & 1.3 & 18 & Narukawa et al. (2003) \\
\hline Alert, Canada & 21 & 6.5 & 7.5 & 1.5 & 37 & Narukawa et al. (2002) \\
\hline Alert, Canada & 14 & 2 & 4 & 1 & 21 & Kawamura et al. (1996b) \\
\hline Alert, Canada & 14 & 4 & 4.1 & 1.6 & 24 & Kawamura et al. (2005) \\
\hline Sevettijarvi, Finland & 21 & 16 & 23 & 6 & 66 & Kerminen et al. (1999) \\
\hline Sevettijarvi, Finland & 63 & & 45 & 16 & 124 & Fridlind et al. (2000) \\
\hline Syowa Station, Antarctic & 4.6 & 0.9 & 17 & 0.9 & 23 & Kawamura et al. (1996a) \\
\hline \multicolumn{7}{|l|}{ Biomass burning aerosols } \\
\hline Rondônia, Brazil & 1356 & 188 & 277 & 47 & 1868 & This study \\
\hline
\end{tabular}




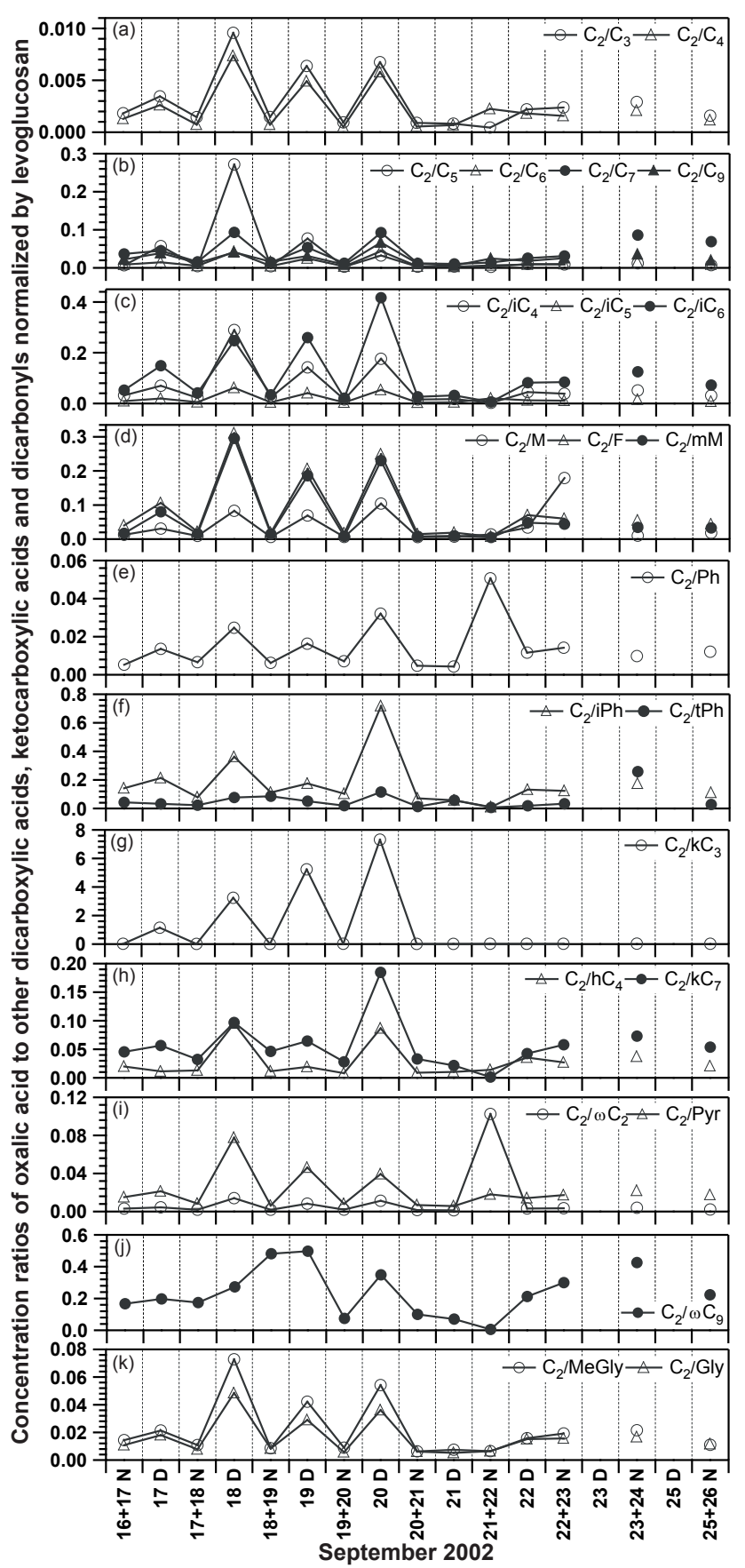

Fig. 5. Diurnal variations of the concentration ratios of oxalic acid to (a) smaller-molecular weight $\left(\mathrm{C}_{3}\right.$ and $\left.\mathrm{C}_{4}\right)$, (b) larger-molecular weight $\left(\mathrm{C}_{5}, \mathrm{C}_{6}, \mathrm{C}_{7}\right.$ and $\left.\mathrm{C}_{9}\right)$, (c) branched $\left(\mathrm{iC}_{4}, \mathrm{iC}_{5}\right.$ and $\left.\mathrm{iC}_{6}\right)$, (d) aliphatic unsaturated $(\mathrm{M}, \mathrm{F}$ and $\mathrm{mM}),(\mathbf{e}-\mathbf{f})$ aromatic unsaturated $(\mathrm{Ph}, \mathrm{iPh}$ and $\mathrm{tPh})$ and $(\mathbf{g}-\mathbf{h})$ multifunctional $\left(\mathrm{kC}_{3}, \mathrm{hC}_{4}\right.$ and $\left.\mathrm{kC}_{7}\right)$ dicarboxylic acids, (i-j) ketocarboxylic acids $\left(\omega \mathrm{C}_{2}, \mathrm{Pyr}\right.$ and $\omega \mathrm{C}_{9}$ ) and (k) $\alpha$-dicarbonyls (MeGly and Gly) normalized by levoglucosan in biomass burning aerosols. See Table 1 for abbreviations.

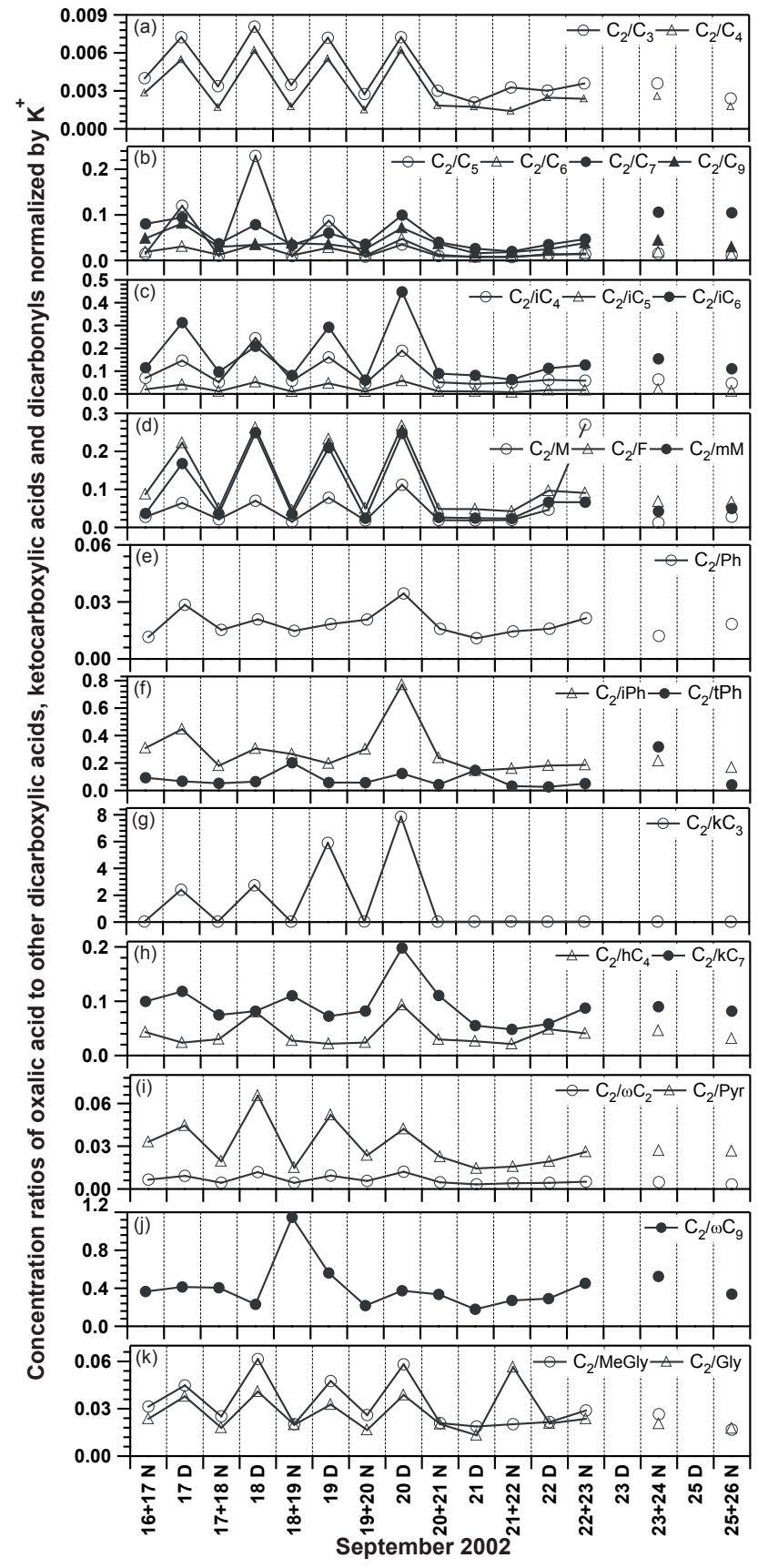

Fig. 6. Diurnal variations of the concentration ratios of oxalic acid to (a) smaller-molecular weight $\left(\mathrm{C}_{3}\right.$ and $\left.\mathrm{C}_{4}\right)$, (b) larger-molecular weight $\left(\mathrm{C}_{5}, \mathrm{C}_{6}, \mathrm{C}_{7}\right.$ and $\left.\mathrm{C}_{9}\right)$, (c) branched $\left(\mathrm{iC}_{4}, \mathrm{iC}_{5}\right.$ and $\left.\mathrm{iC}_{6}\right)$, (d) aliphatic unsaturated (M, F and $\mathrm{mM}),(\mathbf{e}-\mathbf{f})$ aromatic unsaturated $(\mathrm{Ph}, \mathrm{iPh}$ and $\mathrm{tPh})$ and $(\mathrm{g}-\mathbf{h})$ multifunctional $\left(\mathrm{kC}_{3}, \mathrm{hC}_{4}\right.$ and $\left.\mathrm{kC}_{7}\right)$ dicarboxylic acids, (i-j) ketocarboxylic acids $\left(\omega \mathrm{C}_{2}\right.$, Pyr and $\left.\omega \mathrm{C}_{9}\right)$ and (k) $\alpha$-dicarbonyls (MeGly and Gly) normalized by potassium ion in biomass burning aerosols. See Table 1 for abbreviations.

we have observed higher carbon-based concentrations of dicarboxylic acids and related compounds in daytime (Figs. 2 and 3). 


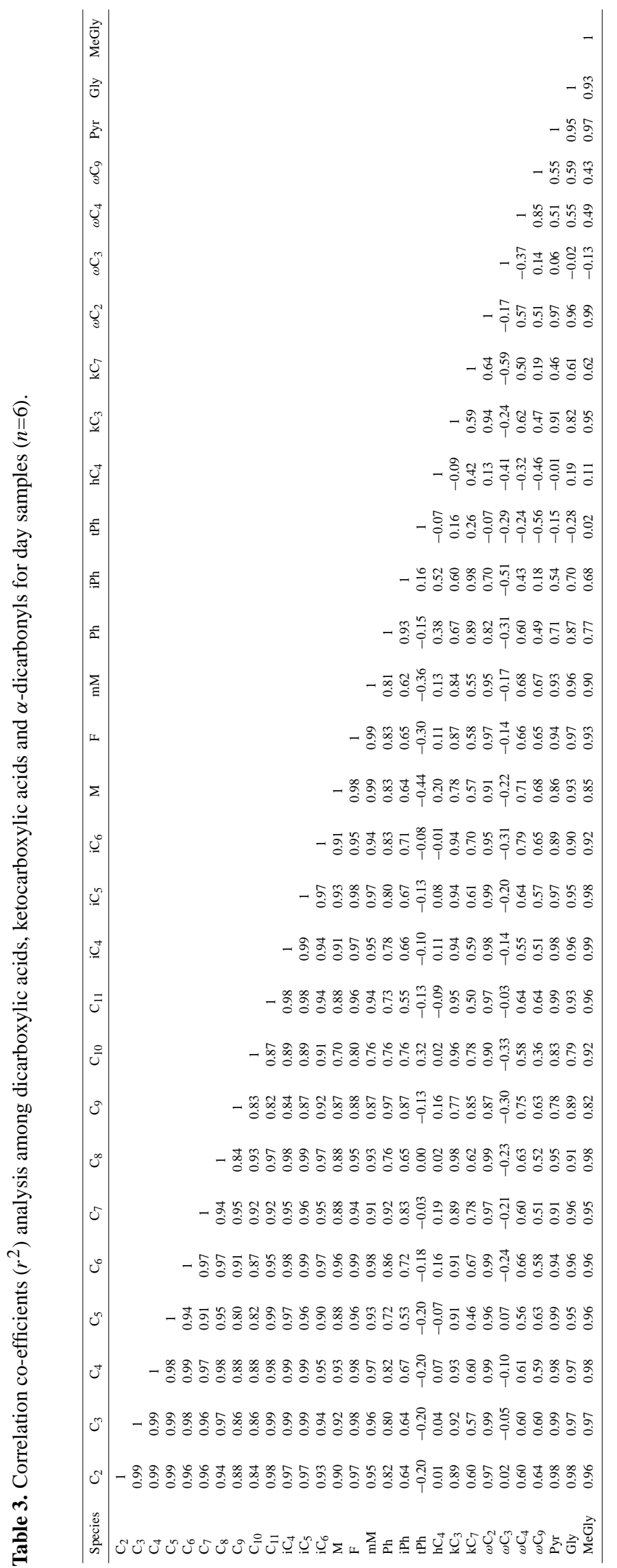

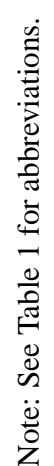




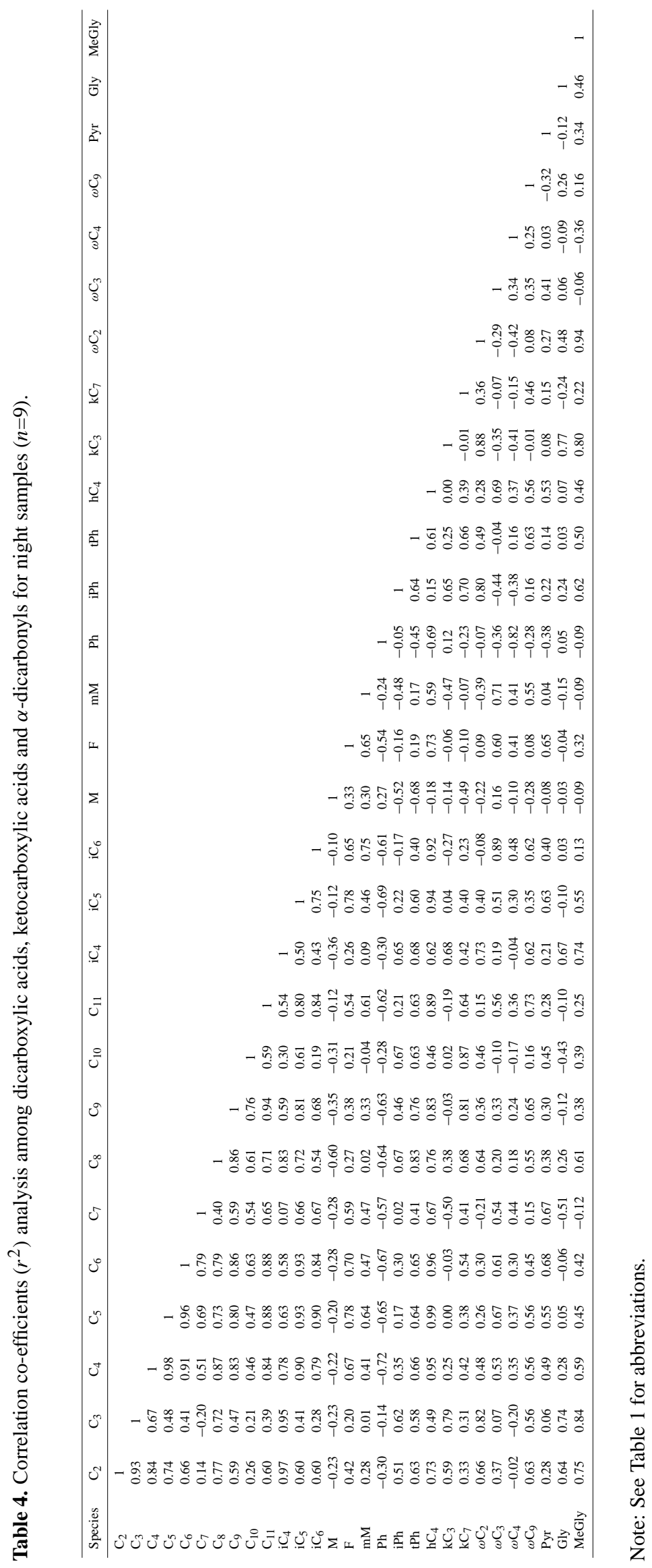


The prevailing combustion phases may have some effect on the observed diurnal variations of dicarboxylic acids and related compounds. Gao et al. (2003) reported that the $\mathrm{K}^{+} /$levoglucosan ratio in aerosols produced from savanna fires was 33.3 for flaming combustion and 0.2-0.6 for smoldering combustion. These results suggest that aerosols produced from flaming phases should have a higher $\mathrm{K}^{+} /$levoglucosan ratio. Higher $\mathrm{K}^{+} /$levoglucosan ratios (average $0.78 \pm 0.3$ ) for daytime samples and lower ratios (average $0.51 \pm 0.2$ ) for nighttime, as well as successive day and nighttime samples, have already been reported for the same group of samples used in this study (Kundu et al., 2010).

\subsection{Chemical degradation of dicarboxylic acids, keto- carboxylic acids and $\alpha$-dicarbonyls}

The chemical production of $\mathrm{C}_{2}-\mathrm{C}_{9}$ dicarboxylic acids from the UV irradiation of the oleic acid- $\mathrm{O}_{3}-\mathrm{OH}$ radical system in the laboratory, followed by their chemical degradation after $20 \mathrm{~h}$ has been observed (Matsunaga et al., 1999). Kalberer et al. (2000) identified gas phase pentanal as a main product from a smog chamber experiment with the cyclohexeneozone system, as well as oxalic $\left(\mathrm{C}_{2}\right)$, malonic $\left(\mathrm{C}_{3}\right)$, succinic $\left(\mathrm{C}_{4}\right)$, and adipic $\left(\mathrm{C}_{6}\right)$ acids, multifunctional dicarboxylic acids (hydroxyglutaric and hydroxyadipic), and oxocarboxylic acids (4-oxobutanoic acid, 5-oxopentanoic acid and 6-oxohexanoic acid) in the aerosol phase. Interestingly, the yield of smaller-MW dicarboxylic acids and related compounds $\left(\mathrm{C}_{2}-\mathrm{C}_{5}\right)$ was higher than that of larger-MW dicarboxylic acids $\left(\mathrm{C}_{6}\right)$, suggesting that $\mathrm{C}_{2}-\mathrm{C}_{5}$ dicarboxylic acids are likely produced due to the photochemical degradation of adipic $\left(\mathrm{C}_{6}\right)$ acid in the cyclohexene-ozone system.

Kawamura et al. (1999) have suggested, based on the higher ratios of $\mathrm{C}_{2} / \mathrm{C}_{4}$ and $\mathrm{C}_{3} / \mathrm{C}_{4}$ in the equatorial Pacific than in the midlatitudes of the Pacific, that $\mathrm{C}_{2}$ and $\mathrm{C}_{3}$ dicarboxylic acids were likely produced by the oxidative degradation of $\mathrm{C}_{4}$ and longer chain dicarboxylic acids in the aerosols. Strong anti-correlations between the relative abundance of oxalic acid to total n-saturated dicarboxylic acids $\left(\mathrm{C}_{2}-\mathrm{C}_{10}\right)$ and some high carbon number dicarboxylic acids [methylmalonic $\left(\mathrm{iC}_{4}\right)$, maleic $(\mathrm{M})$, methylmaleic $(\mathrm{mM})$, methylsuccinic $\left(\mathrm{iC}_{5}\right)$, adipic $\left(\mathrm{C}_{6}\right)$ and phthalic $\left.(\mathrm{Ph})\right]$, ketocarboxylic acids [glyoxylic $\left(\omega \mathrm{C}_{2}\right)$ and pyruvic (Pyr)], and dicarbonyl [glyoxal (Gly)] have been reported in summer aerosols collected from urban Tokyo (Kawamura and Yasui, 2005). These authors also suggested that longer-chain $\left(\mathrm{C}_{5}-\mathrm{C}_{10}\right)$ dicarboxylic acids were produced through the oxidation of semi-volatile fatty acids (Kawamura and Gagosian, 1990; Kawamura et al., 1996a), which are also the oxidation products of unsaturated fatty acids that are abundant in leaves of higher terrestrial plants and are also emitted from wood burning (Rogge et al., 1998).

Generally, levoglucosan and $\mathrm{K}^{+}$normalized ratios of oxalic acid to other dicarboxylic acids, ketocarboxylic acids and dicarbonyls showed higher values in daytime than in nighttime (Figs. 5 and 6). This suggests that oxalic acid is likely produced photochemically from other dicarboxylic acids, ketocarboxylic acids and dicarbonyls in the biomass burning environment.

\subsection{Primary versus secondary sources of dicarboxylic acids and related compounds}

Primary sources of dicarboxylic acids and related compounds include motor exhausts (Kawamura and Kaplan, 1987; Grosjean, 1989), wood combustion (Rogge et al., 1998; Oros and Simoneit, 2001), forest biomass burning (Narukawa et al., 1999; Falkovich et al., 2005) and the cooking of meat (Rogge et al., 1991). Although it is widely believed that the secondary production of dicarboxylic acids overwhelms the emissions from primary sources, little is known about their secondary production from different precursors, which include ethene and ethyne (Warneck, 2003), toluene and isoprene (Ervens et al., 2004), methylglyoxal (Lim et al., 2005; Carlton et al., 2007), unsaturated fatty acids (Kawamura and Gagosian, 1987; Kawamura and Sakaguchi, 1999; Matsunaga et al., 1999), cycloalkenes (Hatakeyama et al., 1985; Kalberer et al., 2000; Gao et al., 2001), etc.

To better understand the sources and formation mechanisms of dicarboxylic acids and related compounds, we conducted correlation analyses on day and night samples. Tables 3 and 4 show the correlation coefficients among dicarboxylic acids and related compounds for day and night samples, respectively. For day samples, very good correlations were obtained between oxalic $\left(\mathrm{C}_{2}\right)$ acid and other straightchain $\left(\mathrm{C}_{3}-\mathrm{C}_{11}\right)$ and branched-chain $\left(\mathrm{iC}_{4}, \mathrm{iC}_{5}\right.$ and $\left.\mathrm{iC}_{6}\right)$ saturated dicarboxylic acids, unsaturated $(\mathrm{M}, \mathrm{F}, \mathrm{mM}$ and $\mathrm{Ph})$ dicarboxylic acids, multifunctional $\left(\mathrm{kC}_{3}, \mathrm{kC}_{7}\right.$ except $\left.\mathrm{hC}_{4}\right)$ dicarboxylic acids, ketocarboxylic acids $\left(\omega \mathrm{C}_{2}, \omega \mathrm{C}_{4}, \omega \mathrm{C}_{9}\right.$ and Pyr except $\omega \mathrm{C}_{3}$ ) and dicarbonyls (Gly and MeGly). Systematically, weaker correlations were observed among oxalic $\left(\mathrm{C}_{2}\right)$ acid and other dicarboxylic acid species and related compounds in nighttime samples, which can be interpreted as resulting from the accumulation of dicarboxylic acids and related compounds within the shallow nocturnal boundary layer and the cessation of photo-production and degradation of dicarboxylic acids and related compounds at night.

These correlations suggest a similarity in the sources of dicarboxylic acids and related compounds. The sources are likely either primary emission or secondary production, which are strongly connected to each other by chain reactions transforming other dicarboxylic acids and related compounds to oxalic acid. This is also supported by the higher abundance of oxalic acid relative to other dicarboxylic acids and related compounds (Figs. 5 and 6) and fair to good correlations between temperature and oxalic acid to other dicarboxylic acids (Fig. 7) in daytime. Assuming that other dicarboxylic acids and related compounds are converted to oxalic $\left(\mathrm{C}_{2}\right)$ acid, particularly in daytime due to 
Table 5. Correlation coefficients $\left(r^{2}\right)$ for the concentrations of dicarboxylic acids, ketocarboxylic acids and $\alpha$-dicarbonyls against potassium $\left(\mathrm{K}^{+}\right)$, carbon monoxide (CO), organic (OC) and elemental carbon (EC) in the atmospheric aerosols collected in day- and night-time during the intensive burning period (16-26 September 2002) from Rondônia, Brazil under the framework of LBA-SMOCC campaign.

\begin{tabular}{|c|c|c|c|c|c|c|c|c|}
\hline \multirow{2}{*}{ Compound } & \multicolumn{2}{|c|}{$\mathrm{K}^{+}$} & \multicolumn{2}{|c|}{$\mathrm{CO}$} & \multicolumn{2}{|c|}{ OC } & \multicolumn{2}{|c|}{$\mathrm{EC}$} \\
\hline & Day & Night & Day & Night & Day & Night & Day & Night \\
\hline & \multicolumn{8}{|c|}{ Saturated n-dicarboxylic acids } \\
\hline Oxalic, $\mathrm{C}_{2}$ & 0.95 & 0.49 & 0.92 & 0.33 & 0.95 & 0.57 & 0.68 & 0.07 \\
\hline Malonic, $\mathrm{C}_{3}$ & 0.98 & 0.33 & 0.94 & 0.08 & 0.98 & 0.39 & 0.72 & 0.09 \\
\hline Succinic, $\mathrm{C}_{4}$ & 0.98 & 0.82 & 0.94 & 0.59 & 0.98 & 0.79 & 0.72 & 0.31 \\
\hline Glutaric, $\mathrm{C}_{5}$ & 0.96 & 0.82 & 0.89 & 0.77 & 0.96 & 0.85 & 0.73 & 0.34 \\
\hline Adipic, $\mathrm{C}_{6}$ & 0.98 & 0.72 & 0.97 & 0.63 & 0.98 & 0.72 & 0.67 & 0.23 \\
\hline Pimelic, $\mathrm{C}_{7}$ & 0.94 & 0.45 & 0.90 & 0.59 & 0.93 & 0.48 & 0.67 & 0.11 \\
\hline Suberic, $\mathrm{C}_{8}$ & 0.99 & 0.54 & 0.90 & 0.24 & 0.99 & 0.55 & 0.79 & 0.19 \\
\hline Azelaic, $\mathrm{C}_{9}$ & 0.86 & 0.68 & 0.86 & 0.39 & 0.83 & 0.59 & 0.42 & 0.21 \\
\hline Sebacic, $\mathrm{C}_{10}$ & 0.92 & 0.28 & 0.73 & 0.12 & 0.88 & 0.23 & 0.80 & 0.11 \\
\hline \multirow[t]{2}{*}{ Undecanedioic, $\mathrm{C}_{11}$} & 0.98 & 0.77 & 0.89 & 0.56 & 0.98 & 0.68 & 0.74 & 0.18 \\
\hline & \multicolumn{8}{|c|}{ Branched dicarboxylic acids } \\
\hline Isomalonic, $\mathrm{iC}_{4}$ & 0.98 & 0.39 & 0.94 & 0.17 & 0.99 & 0.46 & 0.78 & 0.01 \\
\hline Isosuccinic, $\mathrm{iC}_{5}$ & 0.99 & 0.86 & 0.95 & 0.73 & 0.99 & 0.84 & 0.73 & 0.52 \\
\hline \multirow[t]{2}{*}{ Isoglutaric, $\mathrm{iC}_{6}$} & 0.98 & 0.75 & 0.91 & 0.73 & 0.96 & 0.74 & 0.62 & 0.21 \\
\hline & \multicolumn{8}{|c|}{ Unsaturated dicarboxylic acids } \\
\hline Maleic, M & 0.89 & 0.12 & 0.99 & 0.11 & 0.92 & -0.08 & 0.46 & -0.02 \\
\hline Fumaric, F & 0.96 & 0.77 & 0.98 & 0.84 & 0.97 & 0.76 & 0.61 & 0.41 \\
\hline Methylmaleic, mM & 0.94 & 0.62 & 0.99 & 0.83 & 0.96 & 0.66 & 0.57 & 0.30 \\
\hline Phthalic, $\mathrm{Ph}$ & 0.76 & -0.79 & 0.83 & -0.52 & 0.75 & -0.69 & 0.37 & -0.43 \\
\hline Isophthalic, $\mathrm{iPh}$ & 0.64 & -0.09 & 0.66 & -0.31 & 0.67 & -0.05 & 0.40 & -0.16 \\
\hline \multirow[t]{2}{*}{ Terephthalic, $\mathrm{tPh}$} & -0.05 & 0.44 & -0.38 & 0.37 & -0.11 & 0.60 & 0.39 & 0.37 \\
\hline & \multicolumn{8}{|c|}{ Multifunctional dicarboxylic acids } \\
\hline Hydroxysuccinic, $\mathrm{hC}_{4}$ & -0.02 & 0.84 & 0.25 & 0.73 & 0.06 & 0.84 & 0.05 & 0.35 \\
\hline Ketomalonic, $\mathrm{kC}_{3}$ & 0.97 & -0.08 & 0.80 & -0.27 & 0.96 & 0.00 & 0.84 & 0.00 \\
\hline \multirow[t]{2}{*}{ Ketopimelic, $\mathrm{kC}_{7}$} & 0.61 & 0.14 & 0.58 & -0.11 & 0.57 & 0.07 & 0.35 & -0.17 \\
\hline & \multicolumn{8}{|c|}{ Ketocarboxylic acids } \\
\hline Glyoxylic, $\omega \mathrm{C}_{2}$ & 0.98 & 0.16 & 0.94 & -0.12 & 0.99 & 0.19 & 0.77 & 0.15 \\
\hline 3-Oxopropanoic, $\omega \mathrm{C}_{3}$ & -0.21 & 0.52 & -0.22 & 0.59 & -0.22 & 0.48 & -0.06 & 0.01 \\
\hline 4-Oxobutanoic, $\omega \mathrm{C}_{4}$ & 0.68 & 0.61 & 0.63 & 0.52 & 0.63 & 0.55 & 0.09 & 0.36 \\
\hline 9-Oxononanoic, $\omega \mathrm{C}_{9}$ & 0.59 & 0.47 & 0.59 & 0.33 & 0.55 & 0.50 & -0.01 & 0.09 \\
\hline \multirow[t]{2}{*}{ Pyruvic acid, Pyr } & 0.95 & 0.28 & 0.89 & 0.35 & 0.96 & 0.28 & 0.78 & 0.01 \\
\hline & \multicolumn{8}{|c|}{$\alpha$-dicarbonyls } \\
\hline Glyoxal, Gly & 0.92 & 0.00 & 0.95 & -0.19 & 0.93 & 0.04 & 0.62 & -0.21 \\
\hline Methylglyoxal, MeGly & 0.97 & 0.35 & 0.89 & 0.19 & 0.97 & 0.43 & 0.84 & 0.35 \\
\hline
\end{tabular}

photochemical degradation, it can be concluded based on the linear relationship between oxalic acid and other dicarboxylic acids and related compounds [ $y$ (other dicarboxylic acid and related compounds) $=1.03$ (oxalic acid) +243.5$]$ that, on average, $77 \%$ of the oxalic $\left(\mathrm{C}_{2}\right)$ acid are produced from other dicarboxylic acids and related compounds. The remaining $23 \%$ are likely produced from direct emissions, or are chemically produced from other unknown precursors.

Gao et al. (2003) report the emission ratios of oxalic $\left(\mathrm{C}_{2}\right)$ acid to succinic $\left(\mathrm{C}_{4}\right)$ acid and to glutaric $\left(\mathrm{C}_{5}\right)$ acid in the aerosols of savanna plumes to be 0.16 and 2.5 , respectively (Gao et al., 2003). In our data, the $\left(\mathrm{C}_{2} / \mathrm{C}_{4}\right)$ ratio is 3.5 and 2.9 times higher than that of savanna plume aerosols during day and nighttime, respectively, and the $\left(\mathrm{C}_{2} / \mathrm{C}_{5}\right)$ ratio is 35 and 10 times higher during daytime and nighttime, respectively. These findings substantiate the dominant secondary production of oxalic $\left(\mathrm{C}_{2}\right)$ acid due to the degradation of succinic $\left(\mathrm{C}_{4}\right)$ and glutaric $\left(\mathrm{C}_{5}\right)$ acids. The emission ratios of oxalic acid $\left(\mathrm{C}_{2}\right) / \mathrm{K}^{+}$and succinic acid $\left(\mathrm{C}_{4}\right) / \mathrm{K}^{+}$as well as oxalic acid $\left(\mathrm{C}_{2}\right) /$ levoglucosan and succinic acid $\left(\mathrm{C}_{4}\right) /$ levoglucosan 


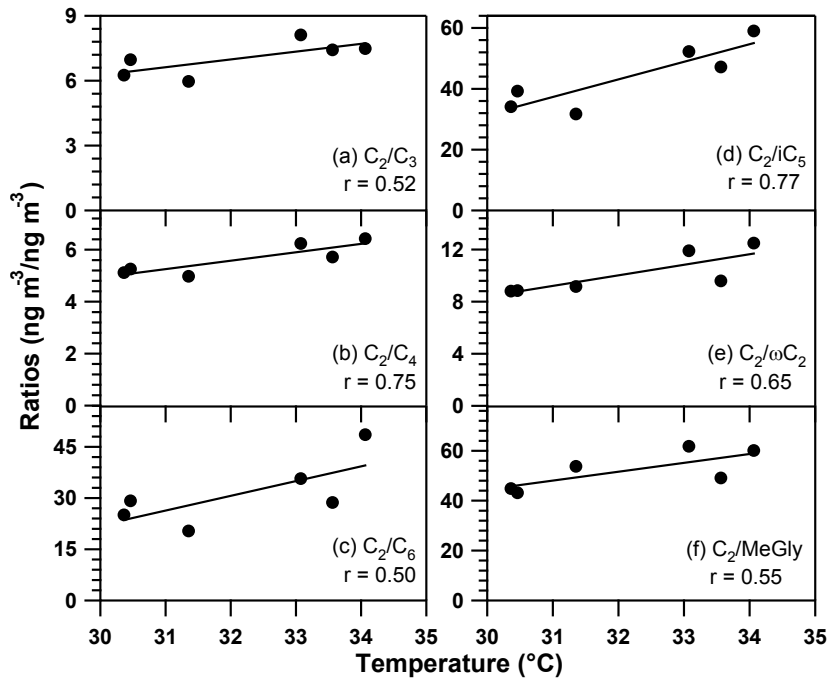

Fig. 7. Relations of the ratios of oxalic acid to other selected dicarboxylic acids and related compounds with temperature. See Table 1 for abbreviations.

can be derived from Gao et al. (2003) for aerosols collected from fresh plumes of savanna fires. Ratios of both dicarboxylic acids to $\mathrm{K}^{+}$and levoglucosan are 0.05 and 0.03 , respectively. Gao et al. (2003) also showed that dicarboxylic acid ratios with respect to $\mathrm{K}^{+}$increased to 0.25 for oxalic $\left(\mathrm{C}_{2}\right)$ acid and to 0.15 for succinic $\left(\mathrm{C}_{4}\right)$ acid in plumes aged over $40 \mathrm{~min}$. A higher average value for oxalic $\left(\mathrm{C}_{2}\right)$ acid $(0.78)$ and a similar average value for succinic $\left(\mathrm{C}_{4}\right)$ acid (0.14) was obtained for our day and night samples. Sillanpää et al. (2005) reported higher enrichment of oxalate (10) and succinate (5) with respect to $\mathrm{K}^{+}$in the case of boreal wildfire smoke transported long distances.

Most of the dicarboxylic acids and related compounds showed moderate to strong correlations with the biomass burning tracers $\left(\mathrm{K}^{+}, \mathrm{CO}\right.$ and $\left.\mathrm{EC}_{a}\right)$ and $\mathrm{OC}$ except for terephthalic $(\mathrm{tPh})$, malic $\left(\mathrm{hC}_{4}\right)$ and 3-oxopropanoic $\left(\omega \mathrm{C}_{3}\right)$ acids in daytime, and maleic $(\mathrm{M})$, phthalic $(\mathrm{Ph})$, isophthalic $(\mathrm{iPh})$, ketomalonic $\left(\mathrm{kC}_{3}\right)$ and ketopimelic $\left(\mathrm{kC}_{7}\right)$ acids, and glyoxal (Gly) in nighttime (Table 5). It has also been previously reported that dicarboxylic acids and related compounds correlated well with the biomass burning tracers $\left(\mathrm{K}^{+}, \mathrm{BC}_{e}\right.$ and CO) (Graham et al., 2002; Mayol-Bracero et al., 2002). This suggests that the dicarboxylic acids and related compounds are in part directly emitted from biomass burning. Correlations of dicarboxylic acids and related compounds against biomass burning tracers $\left(\mathrm{K}^{+}, \mathrm{CO}\right.$ and $\left.\mathrm{EC}_{\mathrm{a}}\right)$ and $\mathrm{OC}$ are systematically weaker in nighttime than in daytime (Table 5). These results further suggest the reduced prevalence of biomass burning at night.

\section{Conclusion}

This study demonstrates, for the first time, the molecular distributions of dicarboxylic acids, ketocarboxylic acids and dicarbonyls in the full range of $\mathrm{C}_{2}-\mathrm{C}_{11}$ in biomass burning aerosols. Oxalic $\left(\mathrm{C}_{2}\right)$ acid is the most abundant among these species, followed by succinic $\left(\mathrm{C}_{4}\right)$, malonic $\left(\mathrm{C}_{3}\right)$ and glyoxylic $\left(\omega \mathrm{C}_{2}\right)$ acids. Higher loadings of total dicarboxylic acids, total ketocarboxylic acids and total dicarbonyls were found in our biomass burning aerosols than in the aerosols of heavily polluted megacities in East Asia, indicating that biomass burning is a very important source for dicarboxylic acids and related compounds at the regional and global scales. Evidence for the photochemical formation and degradation of dicarboxylic acids in the smoke layers was obtained in this study. Considering the $\mathrm{C}_{3}-\mathrm{C}_{11}$ dicarboxylic acids, ketocarboxylic acids and dicarbonyls as being precursors of oxalic acid, this study has also shown that the secondary formation of oxalic $\left(\mathrm{C}_{2}\right)$ acid via photochemical processes overwhelms the primary production. However, these precursor compounds are also derived predominantly from biomass burning emissions and subsequent photochemical oxidations.

Acknowledgements. This research was supported in part by the Japanese Ministry of Education, Science, Sport and Culture (MEXT) through grant-in-aid number 19204055 and also carried out within the framework of the Smoke, Aerosols, Clouds, Rainfall, and Climate (SMOCC) project, a contribution to the Large-Scale Biosphere-Atmosphere Experiment in Amazonia (LBA). The authors gratefully acknowledge financial support by the European Commission (contract No. EVK-CT-2001-00110 SMOCC) and by the Max Planck Society. We are thankful to all members of the LBA-SMOCC and LBA-RACCI Science Teams for their support during the field campaign, in particular J. von Jouanne and A. Camargo for their support in setting up the sampling site and to G. Frank for his help in the preparation of the sampling devices. S. K. acknowledges financial support from MEXT and the cooperation of S. Decesari for supplying additional data gained under the framework of LBA-SMOCC campaign.

Edited by: A. Hofzumahaus

\section{References}

Allen, A. G. and Miguel, A. H.: Biomass burning in the AmazonCharacterization of the ionic component of aerosols generated from flaming and smoldering rain-forest and savanna, Environ. Sci. Technol., 29(2), 486-493, 1995.

Andreae, M. O. and Merlet, P.: Emission of trace gases and aerosols from biomass burning, Global Biogeochem. Cycles, 15, 955, 2001.

Andreae, M. O., Artaxo, P., Brandão C., Carswell, F. E., Ciccioli, P., da Costa, A. L., Culf, A. D., et al.: Biogeochemical cycling of carbon, water, energy, trace gases and aerosols in Amazonia: The LBA-EUSTACH experiments, J. Geophys. Res., 107, 8066, doi:10.1029/2001JD000524, 2002. 
Andreae, M. O., Rosenfeld, D., Artaxo, P., Costa, A. A., Frank, G. P., Longo, K. M., and Silva-Dias, M. A. F.: Smoking rain clouds over the Amazon, Science, 303(5662), 1337-1342, 2004.

Andreae, M. O. and Rosenfeld, D.: Aerosol-cloud-precipitation interactions. Part 1. The nature and sources of cloud-active aerosols, Earth Sci. Rev., 89, 13-41, 2008.

Asa-Awuku, A., Sullivan, A. P., Hennigan, C. J., Weber, R. J., and Nenes, A.: Investigation of molar volume and surfactant characteristics of water-soluble organic compounds in biomass burning aerosol, Atmos. Chem. Phys., 8, 799-812, 2008, http://www.atmos-chem-phys.net/8/799/2008/.

Carlton, A. G., Turpin, B. J., Altieri, K. E., Seitzinger, S., Reff, A., Lim, H.-J., and Erven, B.: Atmospheric oxalic acid and SOA production from glyoxal: Results of aqueous photooxidation experiments, Atmos. Environ., 41, 7588-7602, 2007.

Cruz, C. N. and Pandis, S. N.: A study of the ability of secondary organic aerosol to act as cloud condensation nuclei, Atmos. Environ., 31, 2205-2214, 1997.

Cruz, C. N. and Pandis, S. N.: The effect of organic coatings on the cloud condensation nuclei activation of inorganic atmospheric aerosol, J. Geophys. Res., 103, 13111-13123, 1998.

Decesari, S., Fuzzi, S., Facchini, M. C., Mircea, M., Emblico, L., Cavalli, F., Maenhaut, W., Chi, X., Schkolnik, G., Falkovich, A., Rudich, Y., Claeys, M., Pashynska, V., Vas, G., Kourtchev, I., Vermeylen, R., Hoffer, A., Andreae, M. O., Tagliavini, E., Moretti, F., and Artaxo, P.: Characterization of the organic composition of aerosols from Rondônia, Brazil, during the LBASMOCC 2002 experiment and its representation through model compounds, Atmos. Chem. Phys., 6, 375-402, 2006, http://www.atmos-chem-phys.net/6/375/2006/.

Ervens, B., Feingold, G., Frost, G, J., and Kreidenweis, S. M.: A modeling study of aqueous production of dicarboxylic acids: 1 . Chemical pathways and speciated organic mass production, J. Geophys. Res., 109, D15205, doi:10.1029/2003JD004387, 2004.

Falkovich, A. H., Graber, E. R., Schkolnik, G., Rudich, Y., Maenhaut, W., and Artaxo, P.: Low molecular weight organic acids in aerosol particles from Rondônia, Brazil, during the biomassburning, transition and wet periods, Atmos. Chem. Phys., 5, 781797, 2005,

http://www.atmos-chem-phys.net/5/781/2005/.

Fisseha, R., Dommen, J., Gaeggelar, K., Weingartner, E., Samburova, V., Kalberer, M., and Baltensperger, U.: Online gas and aerosol measurement of water soluble carboxylic acids in Zurich, J. Geophys. Res., 111, D12316, doi:10.1029/2005JD006782, 2006.

Fuzzi, S., Decesari, S., Facchini, M. C., Cavalli, F., Emblico, L., Mircea, M., Andreae, M. O., Trebs, I., Hoffer, A., Guyon, P., Artaxo, P., Rizzo, L. V., Lara, L. L., Pauliquevis, T., Maenhaut, W., Raes, N., Chi, X., Mayol-Bracero, O. L., Soto-García, L. L., Clayes, M., Kourtchev, I., Rissler, J., Swietlicki, E., Tagliavini, E., Schkolnik, G., Falkovich, A. H., Rudich, Y., Fisch, G., and Gatti, L. V.: Overview of the inorganic and organic composition of size-segregated aerosol in Rondônia, Brazil, from the biomass burning period to the onset of the wet season, J. Geophys. Res., 112, D01201, doi:10.1029/2005JD006741, 2007.

Gao, S., Hegg, D. A., Frick, G., Caffrey, P. F., Pasternack, L., Cantrell, C., Sullivan, W., Ambrusko, J., Albrechcinski, T., and Kirchstetter, T. W.: Experimental and modeling studies of secondary organic aerosol formation and some applications to the marine boundary layer, J. Geophys. Res., 106(D21), 2761927634, 2001.

Gao, S., Hegg, D. A., Hobbs, P. V., Kirchstetter, T. W., Magi, B. I., and Sadilek, M.: Water-soluble organic components in aerosols associated with savanna fires in southern Africa: Identification, evolution, and distribution, J. Geophys. Res., 108(D13), 8491, doi:10.1029/2002JD002324, 2003.

Graham, B., Mayol-Bracero, O. L., Guyon, P., Roberts, G. C., Decesari, S., Facchini, M. C., Artaxo, P., Maenhaut, W., Koll, P., and Andreae, M. O.: Water-soluble organic compounds in biomass burning aerosols over Amazonia - 1. Characterization by NMR and GC-MS, J. Geophys. Res., 107(D20), 8047, doi:10.1029/2001JD000336, 2002.

Grosjean, D.: Organic Acids in Southern California Air: Ambient Concentrations, Mobile Source Emissions, in Situ Formation and Removal Processes, Environ. Sci. Technol., 23, 1506-1514, 1989.

Hatakeyama, S., Tanonaka, T., Weng, J., Bandow, H., Takagi, H., and Akimoto, H.: Ozone-cyclohexene reaction in air: Quantitative analyses of particulate products and the reaction mechanism, Environ. Sci. Technol., 19, 935-942, 1985.

Ho, K. F., Cao, J. J., Lee, S. C., Kawamura, K., Zhang, R. J., Chow, J. C., and Watson, J. G.: Dicarboxylic acids, ketocarboxylic acids, and dicarbonyls in the urban atmosphere of China, J. Geophys. Res., 112, D22S27, doi:10.1029/2006JD008011, 2007.

Hoffer, A., Gelencsér, A., Blazsó, M., Guyon, P., Artaxo, P., and Andreae, M. O.: Diel and seasonal variations in the chemical composition of biomass burning aerosol, Atmos. Chem. Phys., 6, 3505-3515, 2006, http://www.atmos-chem-phys.net/6/3505/2006/.

Kalberer, M., Yu, J., Cocker, D. R., Flagan, R. C., and Seinfeld, J. H.: Aerosol formation in the cyclohexene-ozone system, Environ. Sci. Technol., 34, 4894-4901, 2000.

Kaufman, Y. J. and Fraser, R. S.: The effect of smoke particles on clouds and climate forcing, Science, 277(5332), 1636-1639, 1997.

Kaufman, Y. J., Tanre, D., and Boucher, O.: A satellite view of aerosols in the climate system, Nature, 419(6903), 215-223, 2002.

Kawamura, K. and Gagosian, R. B.: Implications of $\omega$ oxocarboxylic acids in the remote marine atmosphere for photooxidation of unsaturated fatty acids, Nature, 325, 330-332, 1987.

Kawamura, K. and Kaplan, I. R.: Motor exhaust emission as a primary source of dicarboxylic acids in Los Angeles ambient air, Environ. Sci. Technol., 21, 105-110, 1987.

Kawamura, K.: Identification of $\mathrm{C}_{2}-\mathrm{C}_{10} \omega$-oxocarboxylic acids, pyruvic acid and $\mathrm{C}_{2}-\mathrm{C}_{3} \alpha$-dicarbonyls in wet precipitation and aerosol samples by capillary GC and GC-MS, Anal. Chem., 65, 3505-3511, 1993.

Kawamura, K. and Gagosian, R. B.: Mid-chain ketocarboxylic acids in the remote marine atmosphere: Distribution patterns and possible formation mechanisms, J. Atmos. Chem., 11, 107-122, 1990.

Kawamura, K. and Ikushima, K.: Seasonal changes in the distribution of dicarboxylic acids in the urban atmosphere, Environ. Sci. Technol., 27, 2227-2235, 1993.

Kawamura, K. and Usukura, K.: Distribution of low molecular weight dicarboxylic acids in the North Pacific aerosol samples, J. Oceanogra., 49, 271-283, 1993. 
Kawamura, K., Sempéré, R., Imai, Y., Fujii, Y., and Hayashi, M.: Water soluble dicarboxylic acids and related compounds in Antarctic aerosols, J. Geophys. Res., 101, 18721-18728, 1996a.

Kawamura, K., Kasukabe, H., and Barrie, L. A.: Source and reaction pathways of dicarboxylic acids, ketoacids, and dicarbonyls in arctic aerosols at polar sunrise, Atmos. Environ., 30, 17091722, 1996b.

Kawamura, K. and Sakaguchi, F.: Molecular distributions of water soluble dicarboxylic acids in marine aerosols over the Pacific Ocean including tropic, J. Geophys. Res., 104, 3501-3509, 1999.

Kawamura, K., Steinberg, S., Ng, L., and Kaplan, I. R.: Wet deposition of low molecular weight mono- and dicarboxylic acids, aldehydes and inorganic species in Los Angeles, Atmos. Environ., 35, 3917-3926, 2001.

Kawamura, K., Kobayashi, M., Tsubonuma, N., Mochida, M., Watanabe, T., and Lee, M.: Organic and inorganic compositions of marine aerosols from East Asia: Seasonal variations of watersoluble dicarboxylic acids, major ions, total carbon and nitrogen, and stable $\mathrm{C}$ and $\mathrm{N}$ isotopic composition, in: Geochemical Investigation in Earth and Space Science: A Tribute to Issac R. Kaplan, edited by: Hill, R. J., Leventhal, J., Aizenshtat, Z., Baedecker, M. J., Claypool, G., Eganhouse, R., Goldhaber, M., and Peters, K., The Geochemical Society, Publications Series No. 9, Elsevier, 243-265, 2004.

Kawamura, K. and Yasui, O.: Diurnal changes in the distribution of dicarboxylic acids, ketocarboxylic acids and dicarbonyls in the urban Tokyo atmosphere, Atmos. Environ., 39, 1945-1960, 2005.

Kerminen, V. M., Teinila, K., Hillamo, R., and Makela, T.: Size segregated chemistry of particulate dicarboxylic acids in the Arctic atmosphere, Atmos. Environ., 33, 2089-2100, 1999.

Khwaja, H. A.: Atmospheric concentrations of carboxylic acids and related compounds at a semiurban site, Atmos. Environ., 29, 127-139, 1995.

Koppmann, R., von Czapiewski, K., and Reid, J. S.: A review of biomass burning emissions, part I: gaseous emissions of carbon monoxide, methane, volatile organic compounds, and nitrogen containing compounds, Atmos. Chem. Phys. Discuss., 5, 10455 10516, 2005,

http://www.atmos-chem-phys-discuss.net/5/10455/2005/.

Kundu, S., Kawamura, K., Andreae, T. W., Hoffer, A., and Andreae, M. O.: Diurnal variation in the water-soluble inorganic ions, organic carbon and isotopic compositions of total carbon and nitrogen in biomass burning aerosols from the LBA-SMOCC campaign in Rondônia, Brazil, J. Aerosol. Sci., 41, 118-133, 2010.

Legrand, M., Preunkert, S., Oliveira, T., Pio, C. A., Hammer, S., Gelencer, A., Kasper-Giebl, A., and Laj, P.: Origin of $\mathrm{C}_{2}-\mathrm{C}_{5}$ dicarboxylic acids in the European atmosphere inferred from yearround aerosol study conducted at a west-east transect, J. Geophys. Res., 112, D23S07, doi:10.1029/2006JD008019, 2007.

Lim, H.-J., Carlton, A. G., and Turpin, B. J.: Isoprene Forms Secondary Organic Aerosol through Cloud Processing: Model Simulations, Environ. Sci. Technol., 39, 4441-4446, doi:10.1021/es048039h, 2005.

Limbeck, A. and Puxbaum, H.: Organic acids in continental background aerosol, Atmos. Environ., 33, 1847-1852, 1999.

Limbeck, A., Puxbaum, H., Otter, L., and Scholes, M. C.: Semivolatile behavior of dicarboxylic acids and other polar organic species at a rural background site (Nylsvley, RSA), Atmos.
Environ., 35(10), 1853-1862, 2001.

Matsunaga, S., Kawamura, K., Nakatsuka, T., and Ohkouchi, N.: Preliminary study on laboratory photochemical formation of low molecular weight dicarboxylic acids from unsaturated fatty acid (oleic acid), Res. Org. Geochem., 14, 19-25, 1999.

Mayol-Bracero, O. L., Guyon, P., Graham, B., Roberts, G., Andreae, M. O., Decesari, S., Facchini, M. C., Fuzzi, S., and Artaxo, P.: Water-soluble organic compounds in biomass burning aerosols over Amazonia - 2. Apportionment of the chemical composition and importance of the polyacidic fraction, J. Geophys. Res., 107(D20), 8091, doi:10.1029/2001JD000522, 2002.

Mircea, M., Facchini, M. C., Decesari, S., Cavalli, F., Emblico, L., Fuzzi, S., Vestin, A., Rissler, J., Swietlicki, E., Frank, G., Andreae, M. O., Maenhaut, W., Rudich, Y., and Artaxo, P.: Importance of the organic aerosol fraction for modeling aerosol hygroscopic growth and activation: a case study in the Amazon Basin, Atmos. Chem. Phys., 5, 3111-3126, 2005, http://www.atmos-chem-phys.net/5/3111/2005/.

Mochida, M., Kawabata, A., Kawamura, K., Hatsushika, H., and Yamazaki, K.: Seasonal variation and origins of dicarboxylic acids in the marine atmosphere over the western North Pacific, J. Geophys. Res., 108, 4193, doi:10.1029/2002JD002355, 2003a.

Mochida, M., Kawamura, K., Umemoto, N., Kobayashi, M., Matsunaga, S., Lim, H. -J., Turpin, B. J., Bates, T. S., and Simoneit, B. R. T.: Spatial distributions of oxygenated organic compounds (dicarboxylic acids, fatty acids, and levoglucosan) in marine aerosols over the western Pacific and off the coast of East Asia: Continental outflow of organic aerosols during the ACE-Asia campaign, J. Geophys. Res., 108(D23), 8638, doi:10.1029/2002JD003249, 2003b.

Narukawa, M., Kawamura, K., Takeuchi, N., and Nakajima, T.: Distribution of dicarboxylic acids and carbon isotopic compositions in aerosols from 1997 Indonesian forest fires, Geophys. Res. Lett., 26(20), 3101-3104, 1999.

Narukawa, M., Kawamura, K., Li, S.-M., and Bottenheim, J. W.: Dicarboxylic acids in the Arctic aerosols and snowpacks collected during ALERT 2000, Atmos. Environ., 36, 2491-2499, 2002.

Narukawa, M., Kawamura, K., Anlauf, K. G., and Barrie, L. A.: Fine and coarse modes of dicarboxylic acids in the Arctic aerosols collected during the Polar Sunrise Experiment 1997 J. Geophys. Res., 108(D18), 4575, doi:10.1029/2003JD003646, 2003.

Oros, D. R. and Simoneit, B. R. T.: Identification and emission factors of molecular tracers in organic aerosols from biomass burning, part 2, Deciduous trees, Appl. Geochem., 16, 1545-1565, 2001.

Ramanathan, V., Crutzen, P. J., Kiehl, J. T., and Rosenfeld, D.: Atmosphere - Aerosols, climate, and the hydrological cycle, Science, 294(5549), 2119-2124, 2001.

Rissler, J., Vestin, A., Swietlicki, E., Fisch, G., Zhou, J., Artaxo, P., and Andreae, M. O.: Size distribution and hygroscopic properties of aerosol particles from dry-season biomass burning in Amazonia, Atmos. Chem. Phys., 6, 471-491, 2006, http://www.atmos-chem-phys.net/6/471/2006/.

Rogge, W. F., Hildemann, L. M., Mazurek, M. A., Cass, G. R., and Simoneit, B. R. T.: Sources of fine organic aerosol. 1. Charbroillers and meat cooking operations, Environ. Sci. Technol., 25, 1112-1125, 1991. 
Rogge, W. F., Hildemann, L. M., Mazurek, M. A., Cass, G. R., and Simoneit, B. R. T.: Sources of fine organic aerosol. 9. Pine, oak, and synthetic log combustion in residential fireplaces, Environ. Sci. Technol., 32, 13-22, 1998.

Röhrl, A. and Lammel, G.: Determination of malic acid and other C4 dicarboxylic acids in atmospheric aerosol samples, Chemosphere, 46, 1195-1199, 2002.

Sempéré, R. and Kawamura, K.: Comparative distributions of dicarboxylic acids and related polar compounds in snow, rain and aerosol from urban atmosphere, Atmos. Environ., 28, 449-459, 1994.

Sempéré, R. and Kawamura, K.: Low molecular weight dicarboxylic acids and related polar compounds in the remote marine rain samples collected from western Pacific, Atmos. Environ., 30, 1609-1619, 1996.

Sempéré, R. and Kawamura, K.: Trans-hemispheric contribution of $\mathrm{C}_{2}-\mathrm{C}_{10} \alpha, \omega$-dicarboxylic acids, and related polar compounds to water-soluble organic carbon in the western Pacific aerosols in relation to photochemical oxidation reactions, Global Biogeochem. Cycles, 17, 1069, doi:10.1029/2002GB001980, 2003.

Sherwood, S.: A microphysical connection among biomass burning, cumulus clouds, and stratospheric moisture, Science, 295, 1272-1275, 2002.
Sillanpää, S., Saarrikoski, S., Hillamo, R., Pennanen, A., Makkonen, U., Spolnik, Z., Grieken, R. V., Koskentalo, T., and Salonen, R.: Chemical composition, mass size distribution and sources analysis of long-range transported wildfire smokes in Helsinki, Sci. Total Environ., 350, 119-135, 2005.

Solomon, P. A., Moyers, J. L., and Fletcher, R.: High-Volume Dichotomous Virtual Impactor for the Fractionation and Collection of Particles According to Aerodynamic Size, Aerosol Sci. Technol., 2, 455-464, 1983.

Wang, G., Liu, N. C., and Wang, L.: Identification of dicarboxylic acids and aldehydes of $\mathrm{PM}_{10}$ and $\mathrm{PM}_{2.5}$ aerosols in Nanjing, China, Atmos. Environ., 36, 1941-1950, 2002.

Wang, H., Kawamura, K., and Yamazaki, K.: Water soluble dicarboxylic acids, ketoacids and dicarbonyls in the atmospheric aerosols over the Southern Ocean and Western Pacific Ocean, J. Atmos. Chem., 53, 43-61, 2006.

Warneck, P.: In-cloud chemistry opens pathway to the formation of oxalic acid in the marine atmosphere, Atmos. Environ., 37, 2423-2427, 2003. 